\title{
Cements, Waters, and Scales: An Integrated Study of the Szeged Geothermal Systems (SE Hungary) to Characterize Natural Environmental Conditions of the Thermal Aquifer
}

\author{
Andrea Varga $\mathbb{D}^{1},{ }^{1}$ Gábor Bozsó, ${ }^{1}$ István Garaguly, ${ }^{1}$ Béla Raucsik, ${ }^{1}$ Attila Bencsik, ${ }^{1,2}$ \\ and Balázs Kóbor ${ }^{1}$ \\ ${ }^{1}$ Department of Mineralogy, Geochemistry and Petrology, University of Szeged, H-6722, Hungary \\ ${ }^{2}$ Geothermal Service Provider Ltd, H-6724, Hungary \\ Correspondence should be addressed to Andrea Varga; raucsikvarga@geo.u-szeged.hu
}

Received 2 July 2018; Revised 19 December 2018; Accepted 17 January 2019; Published 24 April 2019

Guest Editor: Philippe Calcagno

Copyright (C) 2019 Andrea Varga et al. This is an open access article distributed under the Creative Commons Attribution License, which permits unrestricted use, distribution, and reproduction in any medium, provided the original work is properly cited.

\begin{abstract}
The study area, Pannonian Basin (Central Europe), is characterized by high heat flow and presence of low-enthalpy geothermal waters. In the Szeged Geothermal Systems (Hungary), having Miocene to Pliocene sandstone aquifers with dominantly Na$\mathrm{HCO}_{3}$-type thermal water, unwanted carbonate scaling was observed. An integrated approach consisting of host rock and scale mineralogical and petrographic analyses as well as water chemistry led to a better understanding of the characteristic natural (geogenic) environmental conditions of the geothermal aquifers and to highlight their technical importance. Analyses of the reservoir sandstones showed that they are mineralogically immature mixed carbonate-siliciclastic rocks with significant macroporosity. Detrital carbonate grains such as dolomite and limestone fragments appear as important framework components (up to $\sim 20-25 \%$ ). During water-rock interactions, they could serve as a potential source of the calcium and bicarbonate ions, contributing to the elevated scaling potential. Therefore, this sandstone aquifer cannot be considered as a conventional siliciclastic reservoir. In mudrocks, a significant amount of organic matter also occurs, triggering $\mathrm{CO}_{2}$ producing reactions. Correspondingly, framboidal pyrite and ferroan calcite are the main cement minerals in all of the studied sandstone samples which can suggest that calcite saturation state of the thermal fluid is close to equilibrium in oxygen-depleted pore water. Analysis of the dominant carbonate crystals in the scale can suggest that growth of the feather dendrites of low- $\mathrm{Mg}$ calcite was probably driven by rapid $\mathrm{CO}_{2}$ degassing of $\mathrm{CO}_{2}$-rich thermal water under far-from-equilibrium conditions. Based on hydrogeochemical data and related indices for scaling and corrosion ability, the produced bicarbonate-rich (up to $3180 \mathrm{mg} / \mathrm{l}$ ) thermal water has a significant potential for carbonate scaling which supports the aforementioned statement. Taking into consideration our present knowledge of geological setting of the studied geothermal systems, temporal changes in chemical composition and temperature of the thermal water during the heating period can indicate upwelling fluids from a deep aquifer. Regarding the pre-Neogene basement, hydrologic contact with a Triassic carbonate aquifer might be reflected in the observed chemical features such as decreased total dissolved solids and increased bicarbonate content with high scale-forming ability. The proposed upflow of basin-derived water could be channeled by Neogene to Quaternary fault zones, including compaction effects creating fault systems above the elevated basement high. The results may help to understand the cause of the high carbonate scale precipitation rates in geothermal systems tapping sandstone aquifers.
\end{abstract}

\section{Introduction}

Geothermal systems are often characterized by the interaction of complex processes as discussed elsewhere [1]. Therefore, geothermal exploration is increasingly focusing on the extensive integration of multidisciplinary data from production technology to hydrogeochemistry and geological researches [1-8]. Unfortunately, many geothermal installations (e.g., hydrothermal cascade systems) face important operational challenges such as unwanted scaling accompanying the exploitation of high-temperature waters with high salinity and gas content from deep wells [6]. General 
characteristics of scales depend on natural conditions (e.g., geological setting, reservoir type, physicochemical properties, and hydrogeological and hydrochemical features) as well as man-made ones (e.g., well depth, flow rate, operating pressure, substrate material, and effects of biological processes) [5-8].

As a scale component, calcium carbonate $\left(\mathrm{CaCO}_{3}\right.$, aragonite, and/or calcite) precipitation is widespread in low- to moderate-enthalpy geothermal facilities tapping deep limestone and dolomite aquifers [6,7]. Although the aquifers of the Szeged Geothermal Systems (SE Hungary, Great Hungarian Plain) are traditionally considered being siliciclastic ones (mainly very fine- to fine-grained sandstones) with dominantly $\mathrm{Na}-\mathrm{HCO}_{3}$-type thermal water $[3,9]$, relatively high carbonate scale deposition rates have been observed especially in the pipes between the production wells and their buffer tanks [7]. In Szeged, construction of a new districtheating geothermal system is in progress (Figure 1; wells $\mathrm{H}-1$ and $\mathrm{H}-2$ ), so a better characterization of the geothermal reservoir is essential to understand the water-rock interactions in this region.

Recently, some papers reported the man-made (technica1/operational) effects of the district-heating geothermal systems in Szeged $[2-4,7]$. Additionally, hydrogeological and hydrochemical conditions in the Great Hungarian Plain were extensively studied applying state-of-the-art geochemical methods [9-18]. Mineralogical and micropetrographic features of the Miocene-Pliocene geothermal reservoir sandstones in the study area and the related information about scaling potential, however, have not received much attention in the literature.

In this study, we include site-specific data from mineralogical and petrographic analyses of sandstone and mudrock samples collected from the $\mathrm{H}-1$ exploration well (Figure 1) to describe characteristic natural (geogenic) environmental conditions of the geothermal aquifers and to highlight their technical importance. Furthermore, corresponding to an unconventional approach of the reservoir sandstone-thermal water-scale ternary system, mineralogical and petrographic features of the scales are also described to gain some information about operational processes. In order to a better characterization of the site-specific water-rock interactions, this paper presents general hydrogeochemical characteristics (e.g., temperature, $\mathrm{pH}$, and concentrations of dissolved solids) and scaling properties of the thermal water from production wells operating in Szeged. The results may help to understand the cause of the high carbonate scale precipitation rates in geothermal systems tapping sandstone aquifers. It is important to note, however, that it is beyond the scope of this manuscript to discuss the man-made influences (e.g., nucleation/crystal growth mechanisms vs. corrosion processes, fluid-solid interaction modelling) in detail. This is addressed in previous separate papers and ongoing projects of other research teams $[2-5,7,8]$.

\section{Background}

2.1. Szeged Geothermal Systems. Numerous studies demonstrated that geothermal waters in South Eastern Hungary
(Pannonian Basin, Central Europe) are mainly found at a depth of $0.8-2.4 \mathrm{~km}$ with surface temperatures of $40-98^{\circ} \mathrm{C}$ and are $\mathrm{Na}-\mathrm{HCO}_{3}$-type with some dissolved gases (especially $\mathrm{CH}_{4}$ and $\mathrm{CO}_{2}$ ) and total dissolved solids (TDS) of 2-4 g/l. Generally, they are sourced from Upper Miocene to Pliocene sedimentary units (sandstones, clays, and clayey marls) [3-5, 9, 14, 19].

Szeged, located in the southern part of the Great Hungarian Plain, has one of the largest operating geothermal systems in Hungary where two cascade systems (downtown of Szeged and Újszeged district) are supplying heat to several large communal buildings (Figure 1). Annual thermal water production is $\sim 300,000-320,000 \mathrm{~m}^{3}$. The use of geothermal energy has a long history in Szeged where thermal water is also used for medical purposes and balneotherapy at the famous spas such as "Anna Fürdo"” (Anna well; $52^{\circ} \mathrm{C}$, depth: $944 \mathrm{~m}$, date of drilling: 1927; TDS: $2809 \mathrm{mg} / \mathrm{l})$ and "Napfényfürdő Aquapolis" (Dóra I well, $70^{\circ} \mathrm{C}$, depth: $1551 \mathrm{~m}$, date of drilling: 1958; Dóra II well, $80^{\circ} \mathrm{C}$, depth: $1706 \mathrm{~m}$; TDS: $3169 \mathrm{mg} / \mathrm{l})[3,4,19]$.

Based on published data $[3,4]$, both heating systems are supplied by own well (production well pump pressure: 58 bar) producing fluid with a temperature of $92-95^{\circ} \mathrm{C}$ (TDS: 2500-3000 mg/l). In downtown of Szeged (Figure 1), the production well (B-415) is $1999 \mathrm{~m}$ deep and is screened between 1727 and $1914 \mathrm{~m}$. In Újszeged, the production well (B-748) is $1937 \mathrm{~m}$ deep and is screened between 1733 and $1878 \mathrm{~m}$. The well's pumps directly transfer the thermal water into the buffer tanks where degassing takes place ( $\sim 1$ bar). In order to maintain the reservoir pressure and to dispose the heatdepleted fluid in an environment-friendly manner, thermal water is reinjected into the underground layers through 2 reinjection wells at each location (total depth of the reinjection wells B-745, B-746, B-747, and B-748 is $1396 \mathrm{~m}$, $1750 \mathrm{~m}, 1740 \mathrm{~m}$, and $1225 \mathrm{~m}$, respectively).

The abovementioned two thermal circles supply $\sim 80 \%$ of the buildings (e.g., clinics, department buildings, and dormitories) of the University of Szeged and certain buildings of the local government (e.g., Medical Clinic No. 1, Szeged Swimming Pool). These systems replace a quantity of natural gas of 2.9 million $\mathrm{m}^{3}$ in a year with a capacity of $8.9 \mathrm{MW}_{\mathrm{th}}$ and reduce the emission of $\mathrm{CO}_{2}$ by approximately $5,900 \mathrm{t}$, representing a factor conducive to health in urban areas. Thanks to this the University of Szeged reached $19^{\text {th }}$ place on the appreciated World Ranking List of Green Universities [3, 4].

2.2. Geological Setting. The Neogene-Quaternary Pannonian Basin is a large, approximately $600 \mathrm{~km}$ from east to west and $500 \mathrm{~km}$ from north to south, rift-related extensional basin system in Central Europe, overlying Paleogene basins and Cretaceous folds and thrusts of the greater Alpine fold belt. As a back-arc basin, its opening was controlled by different tectonic processes and the extension was manifested through a set of low angle normal and strike-slip faults resulting in formation of several depressions that are separated by uplifted basement blocks [20-25]. One of these basement highs is the so-called Algyö High between the Szeged and Makó Troughs (Figure 2(a)). The Szeged area setting is above the Algyő High whose structure is still under debate so its 


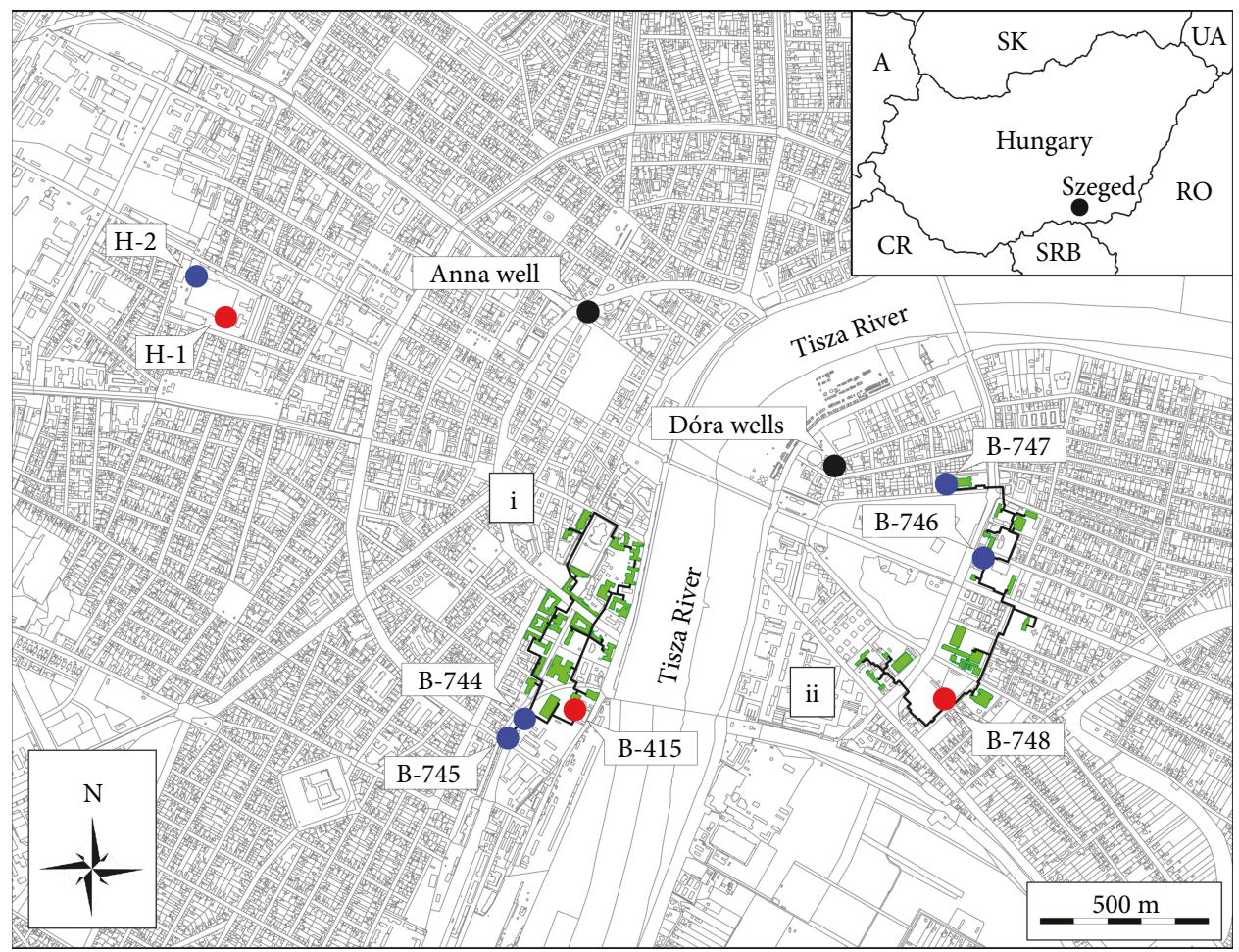

FIGURE 1: Geothermal cascade systems in Szeged (SE Hungary, Central Europe) together with locations of thermal production and reinjection wells (red and blue filled circles, respectively). (i) Geothermal cascade system in downtown of Szeged. (ii) Geothermal cascade system in Újszeged district. Mineralogical and petrographic rock characterization was carried out on core samples from the $\mathrm{H}-1$ exploration well.

stratigraphic subdivision is not known in a satisfactory manner [22-25]. Traditionally, the pre-Cenozoic basement of the study area belongs to the Codru nappe system, Tisza megaunit $[22,23]$. Alternatively, crystalline basement parts of the Algyö High were included into the Biharia nappe system, Dacia mega-unit $[24,25]$. According to the latter interpretation, there is an Alpine shear zone (Codru/Biharia buried contact) within the Algyö basement block (Figure 2(b)).

The Algyö High is made up by metamorphic rocks (e.g., gneisses, mica schists, and amphibolites) with complex internal structure, Upper Paleozoic to Lower Triassic siliciclastic formations as well as Middle Triassic shallow marine mudrocks and carbonates (Figure 3). In the local lithostratigraphy, the Anisian-Ladinian carbonate rocks are classified as Szeged Dolomite Formation which is characterized by a brecciated dark gray dolomite sequence in complicated structural positions $[23,26,27]$. These sediments were deposited on a huge ramp system on the southern margin of the European continental plate and the northern shelf of the Tethys and were completely dolomitized by either fabric-preserving or fabric-destructive processes during multiple dolomitization episodes. Rocks of this formation serve as good aquifers and hydrocarbon reservoirs in this region of Hungary with significant hydrocarbon production [27].

The high relief topographic undulations of the basement were covered by the marine waters of the Paratethys during the Miocene (i.e., 20-10 Ma) and gave way to closely spaced but profoundly different depositional environments [2830]. It has traditionally been believed that the Pannonian Basin was disconnected from the evaporitic basins of the
Paratethys, but massive Badenian (13.8 Ma) evaporites (halite together with sulphates), suggesting oversaturated brine at the bottom water, were recently discovered in the Great Hungarian Plain. Different proposed scenarios could explain how the supposedly brackish Sarmatian could have been hyper or normal saline locally in this area [31].

The Pannonian Basin most likely became an isolated brackish lake ca. $10 \mathrm{Ma}$ ago and the so-called Lake Pannon persisted for about 7-8 Myr. During the Late Miocene and Early Pliocene, the paleo-Danube and paleo-Tisza Rivers progressively filled it with clastic material sourced by the surrounding mountain chains, creating one of the thickest Neogene nonmarine sedimentary sequences in Europe [28]. The central and deepest (average thickness: $2-3 \mathrm{~km}$, locally up to $\sim 7 \mathrm{~km}$ ) depression of the Pannonian Basin is the Great Hungarian Plain, including the studied Szeged area (Figure 2), where the majority of the sediments accumulated [28-30, 32]. Based on recent calculations [33], the water depth of the lake was more than $1000 \mathrm{~m}$ in the deepest subbasins.

Sediments arriving from the Alpine-Carpathian source area were partly accumulated on the flat-lying morphological shelf of the Lake Pannon, whereas their other portions were passing through to the slope and deposited on the deep basin floor [28-30, 33]. The coeval sedimentation reflects the deposition of diachronous and laterally variable formations (Figure 4). Lithostratigraphically, the Endrőd Marl is a distal mudstone and the overlying Szolnok Formation includes deep-water turbidite sandstones, deposited at the toe of slope and in the basin floor. The Algyö Formation is mostly silty mudstone, deposited on the slope, whereas the Ujfalu 


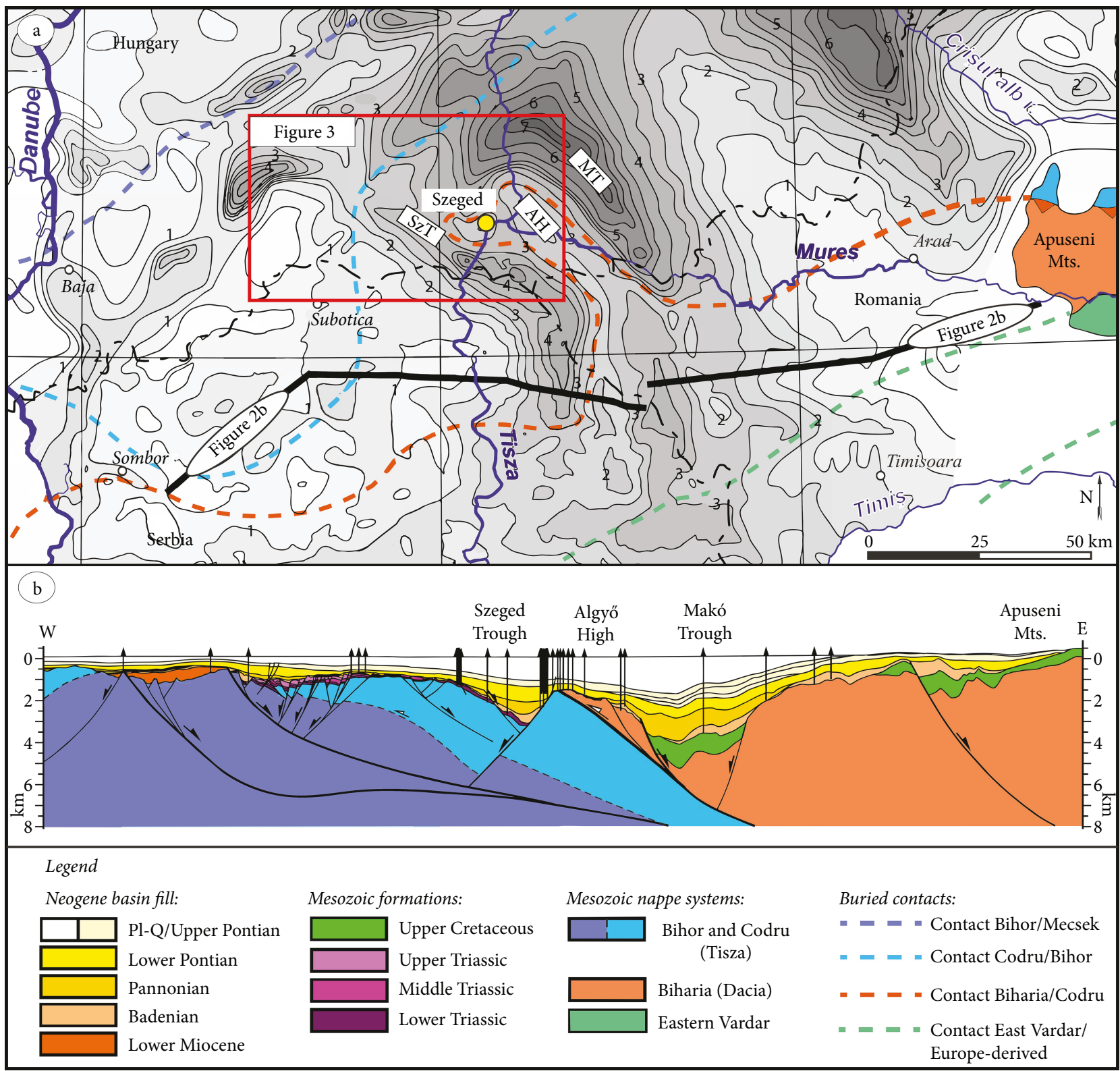

FIGURE 2: Generalized basement map together with a schematic cross section of the southern Pannonian Basin, showing the stratigraphic and structural relationships $[24,25]$. (a) Structural map of the pre-Neogene basement of the Pannonian Basin in SE Hungary and neighboring Serbia and Romania. Isoline numbers are in kilometers. Abbreviations: SzT = Szeged Trough; AH = Algyő High; MT = Makó Trough. (b) WSW-ENE regional transect over the southern part of the Pannonian Basin (Serbia and Romania). The location of the interpreted seismic sections is displayed in (a). Note: the cross section is 4 times vertically exaggerated.

Formation represents the stacked deltaic lobes overlain by alluvial deposits of the Zagyva Formation [28-30, 32]. According to a most recently published article [33], the significant compaction associated with lateral variations of the Neogene sediment thicknesses has created nontectonic normal fault offsets and folds.

The presence of low-enthalpy geothermal waters in the region is thought to be due to high heat flow occurring after the Miocene extension which caused thinning of the lithosphere. During the Neogene extension, the heat flow rate increased from ca. $30 \mathrm{~mW} / \mathrm{m}^{2}$ to $110 \mathrm{~mW} / \mathrm{m}^{2}$. The temperature gradient calculated in wells around Szeged is $67^{\circ} \mathrm{C} / \mathrm{km}$ in the upper successions of the basin $(<3000 \mathrm{~m})[15,34,35]$.
2.3. Hydrogeological and Hydrogeochemical Overview. Hydrodynamically, corresponding to the recognized pore pressure zones, the Pannonian Basin can be subdivided into two principal flow regimes: (i) an upper, gravitydriven, and unconfined flow system; and (ii) a lower, overpressured (up to $40 \mathrm{MPa}$ over the hydrostatic pressure), and confined regime $[10,11,19]$. The most significant characteristic of the zone of transition between the overpressured and normally pressured hydraulic regimes is its widely variable depth between 200 and $1700 \mathrm{~m}$. The transition between the potential fields of the unconfined and confined zones may be gradual in the deep troughs or stepwise abrupt. The latter changes are associated with 


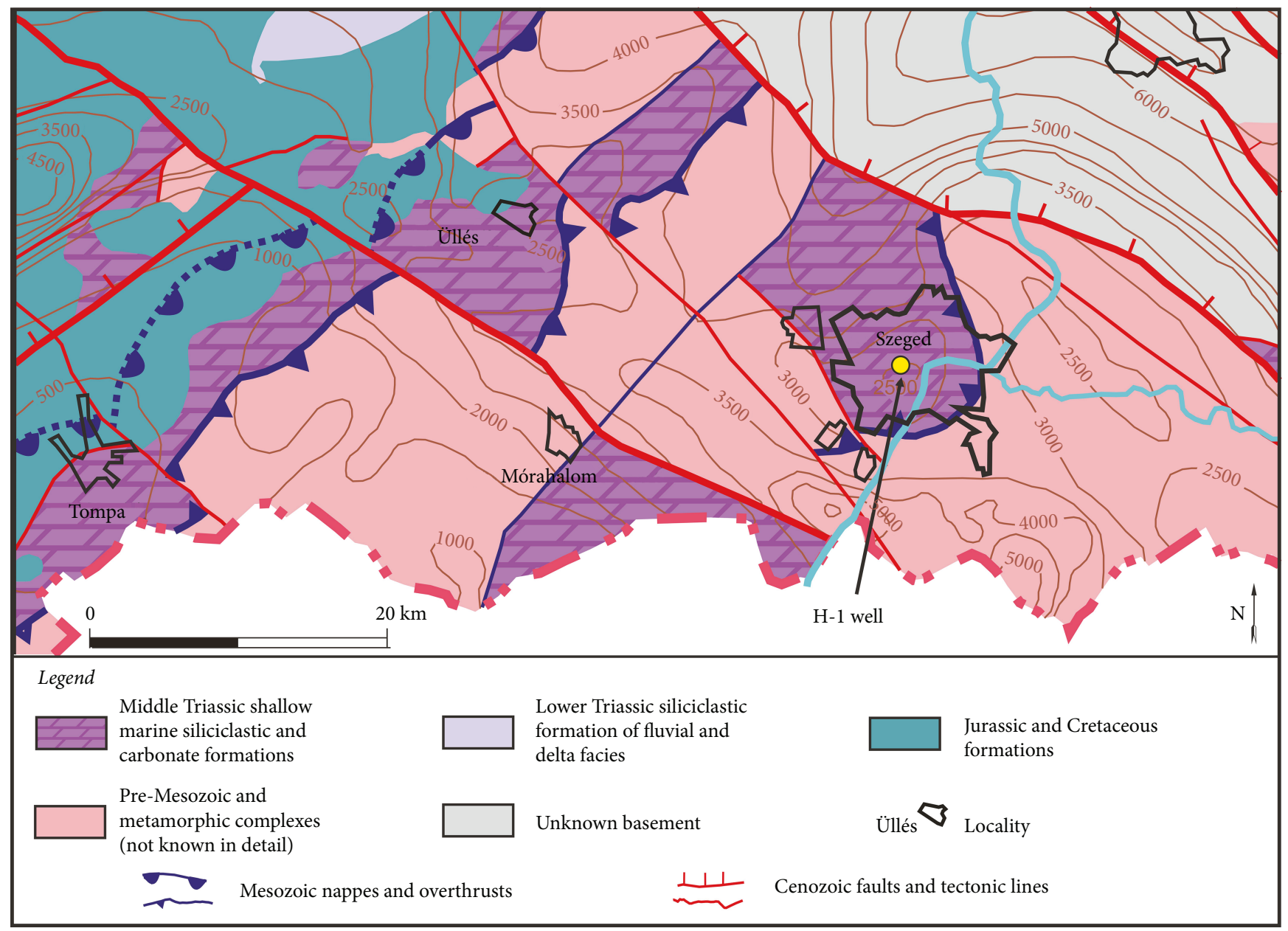

Figure 3: Generalized geological map of the pre-Cenozoic basement of the Szeged area, belonging to the Codru nappe system (Tisza megaunit), and its surroundings $[23,26,27]$. Isoline numbers are in meters. The close vicinity of the town Szeged (study area) has a nearly basement-high position. Reservoir rock characterization was carried out on core samples from the well $\mathrm{H}-1$-penetrated Miocene to Pliocene deposits above the basement.

basement highs and their flanks. It is important to note that the flow's vertical component is uniformly upwards in the overpressured zone $[10,11,13]$.

Inside the sedimentary basin, structural discontinuities, such as faults and fracture zones, and probably also highpermeability sedimentary windows, are preferential pathways of hydraulic pressure dissipation and fluid migration from the confined zone to the unconfined regime. Therefore, the overpressured zone is in hydraulic connection with the upper, gravity-driven zone [11]. Additionally, a strong hydraulic relationship between the pre-Cenozoic basement and the overlying Neogene sequences was also suggested by several authors [12, 33, 36]. Evidences based on cement stratigraphic and diagenetic observations [12, 37] and seismic studies focusing on conductive faults that crosscut the aforementioned formations were also presented [36, 38]. These faults could serve as migration pathways for basement-derived saline waters [36] as well as for hydrocarbons $[33,37]$.

The subsurface of the Great Hungarian Plain has been subdivided into six regional hydrostratigraphic units which are the followings: pre-Neogene aquiclude, pre-Pannonian aquifer, Endrőd aquitard, Szolnok aquifer, Algyő aquitard with aquifer lenses, and Great Plain (Nagyalföld) aquifer $[9,11]$. The Szolnok aquifer, corresponding to the Szolnok Formation (Figure 4), is a cyclic alternation of consolidated sandstones, siltstones, and clayey marl beds, whereas the Great Plain aquifer is dominated by unconsolidated sands and coarse clastics, belonging to the Ujfalu and Zagyva Formations. The entire porous and permeable framework of the Great Hungarian Plain can be considered as a regional and cross-formational hydraulic continuum $[10,11]$. Even though several studies demonstrated hydraulic connection between the main flow regimes, detailed information about water exchange between the basement and the upper aquifers, and in particular, their fault-related hydrochemical evolution, is almost lacking in the study area.

Despite the aforementioned hydraulic continuum, the Pannonian Basin is regarded as a large nonuniform multilayer flow system (Figure 5) in the relevant hydrogeochemical studies [9, 15-18]. Based on chemical considerations, 


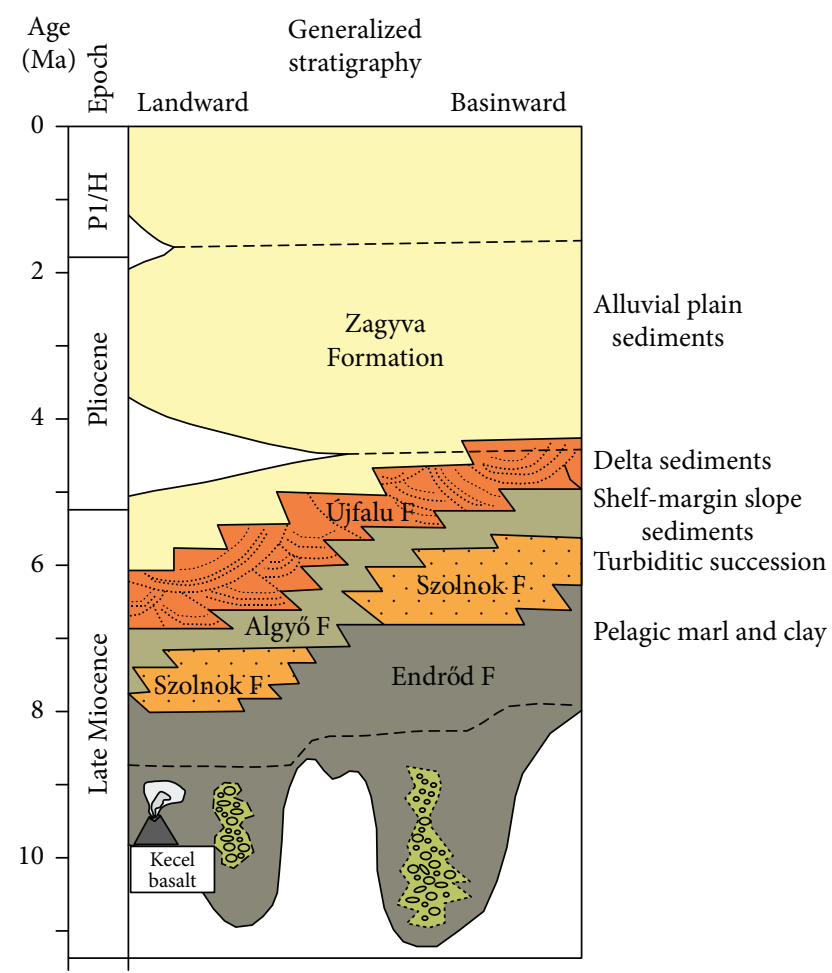

FIGURE 4: Chrono- and lithostratigraphy of the Miocene-Holocene deposits in the study area simplified after Sztanó et al. [29]. Abbreviations: $\mathrm{Pl}=$ Pleistocene; $\mathrm{H}=$ Holocene.

including isotopes, and spatial variability of the dissolved components, distinct water bodies were identified. Within the Pannonian (Late Miocene) sediments, corresponding to the Szolnok aquifer and Algyő aquifer lenses, groundwaters are practically stagnant with $\mathrm{Na}-\mathrm{Cl}$ - to $\mathrm{Na}-\mathrm{HCO}_{3}$-type geochemistry $(>2500 \mathrm{~m}$; TDS $>6 \mathrm{~g} / \mathrm{l})[9,14,15]$. Pannonian/Pontian boundary was considered as the bottom of a regional flow system [15]. Sodium- $\mathrm{HCO}_{3}$-type formation waters of paleometeoric/meteoric origin are present within the Late Miocene to Pliocene sediments, corresponding to the Ujfalu and Zagyva aquifers. Waters in the deepest positions, however, are mixtures of paleometeoric waters and deep waters squeezed out from the thick sequence of the fine-grained Pannonian sediments (Algyő aquitard), underlying the Ujfalu thermal water aquifer [15-18]. The Pleistocene to Holocene terrestrial sediments, depending on the dominant grain size fraction, contain $\mathrm{Na}-\mathrm{HCO}_{3}$-type (finegrained layers) and $\mathrm{Ca} / \mathrm{Mg}-\mathrm{HCO}_{3}$-type (coarse-grained beds) waters $[15,16]$.

It is important to note that the abovementioned $\mathrm{Na}-$ $\mathrm{HCO}_{3}$-type waters contain large amounts of dissolved organic matter (e.g., humic substances, methane, and shortchain aliphatic acid anions). In the study area, different polycyclic aromatic hydrocarbons (PAHs) are characteristic of the waters warmer than $65^{\circ} \mathrm{C}[15,17]$. On the other hand, the Great Hungarian Plain is the principal conventional petroleum producing area in Hungary where basement highs and also the Neogene basin fills have a proven economic value. Furthermore, a large number of hydrocarbon accumulations were reported from turbidite beds of the Miocene
Szolnok Formation all over the basin, mostly in structural traps above basement highs $[29,39]$.

\section{Materials and Methods}

3.1. Sampling and Methodology. For reservoir rock characterization, core samples from the $\mathrm{H}-1$ exploration well (Figure 1) were examined for general lithology and sedimentary structures. The deep well was drilled as a thermal water exploration well in 2017. The available 3 core sections from the well were sampled from the depth interval between 1620 and 1800 meters below sea level, corresponding to the Ujfalu and Algyő Formations, and were taken for detailed mineralogical (X-ray powder diffractometry, XRPD) and petrographic studies (Figure S1). Micropetrographic investigation was done on 20 thin sections impregnated with blue-dyed epoxy resin at the Department of Mineralogy, Geochemistry and Petrology, University of Szeged. In order to distinguish calcite, dolomite, and their ferroan variants, the thin sections were stained with alizarin red-S and potassium ferricyanide as described by Dickson [40]. Additionally, on selected sandstone samples, cathodoluminescence (CL) microscopy was also carried out by a Reliotron VII type cold CL device operating at 8$10 \mathrm{kV}$ and $0.6 \mathrm{~mA}$.

In order to discuss fluid (thermal water/gases) versus solid (reservoir rock/scale) interactions, general hydrochemical data (e.g., fluid chemistry, gas content, $\mathrm{T}$, and $\mathrm{pH}$ ) from available reports of the two geothermal facilities were used. Thermal waters were recovered from pipes at or close to the wellhead. The concentrations of each dissolved component in the water and the phenol index were determined as it is stated in the Hungarian Standards, under numbers MSZ 1484-3:2006 and MSZ 1484-1:2009, respectively. The measurements were made at an accredited laboratory, namely, Aqualabor Ltd (Szeged), using a PerkinElmer Optima 8000 ICP-OES device. As a first step, Langelier and Ryznar Stability Indices (LSI and RSI, respectively) [41] were also calculated for each wells together with the time-related pattern for the heating system in Ujszeged district to determine the scaling and corrosion conditions of the thermal waters in general. In the geothermal cascade system of Ujszeged district, hydrochemical records were made in the heating period of 2017-2018 (from 10/15/2017 to 04/15/2018).

In this paper, the LSI and RSI are used to determine the basic scaling ability and scaling/corrosion potential of thermal water, respectively. Both indices are calculated from the carbonate equilibrium based on the temperature, $\mathrm{pH}$, TDS, alkalinity (which is nearly equal with the concentration of $\mathrm{HCO}_{3}{ }^{-}$in this chemical state of systems) values, as well as the concentration of calcium ion $\left(\mathrm{Ca}^{2+}\right)$. If the LSI is less than zero, the water is unsaturated with respect to calcium carbonate, so scaling is not possible (LSI $=0$ in equilibrium). On the other hand, scale can precipitate if the LSI is higher than zero, corresponding to the supersaturated conditions. With the increase of LSI value, the scaling potential increases. The RSI refers to both scaling and corrosion. If it is less than 6.2, scale 


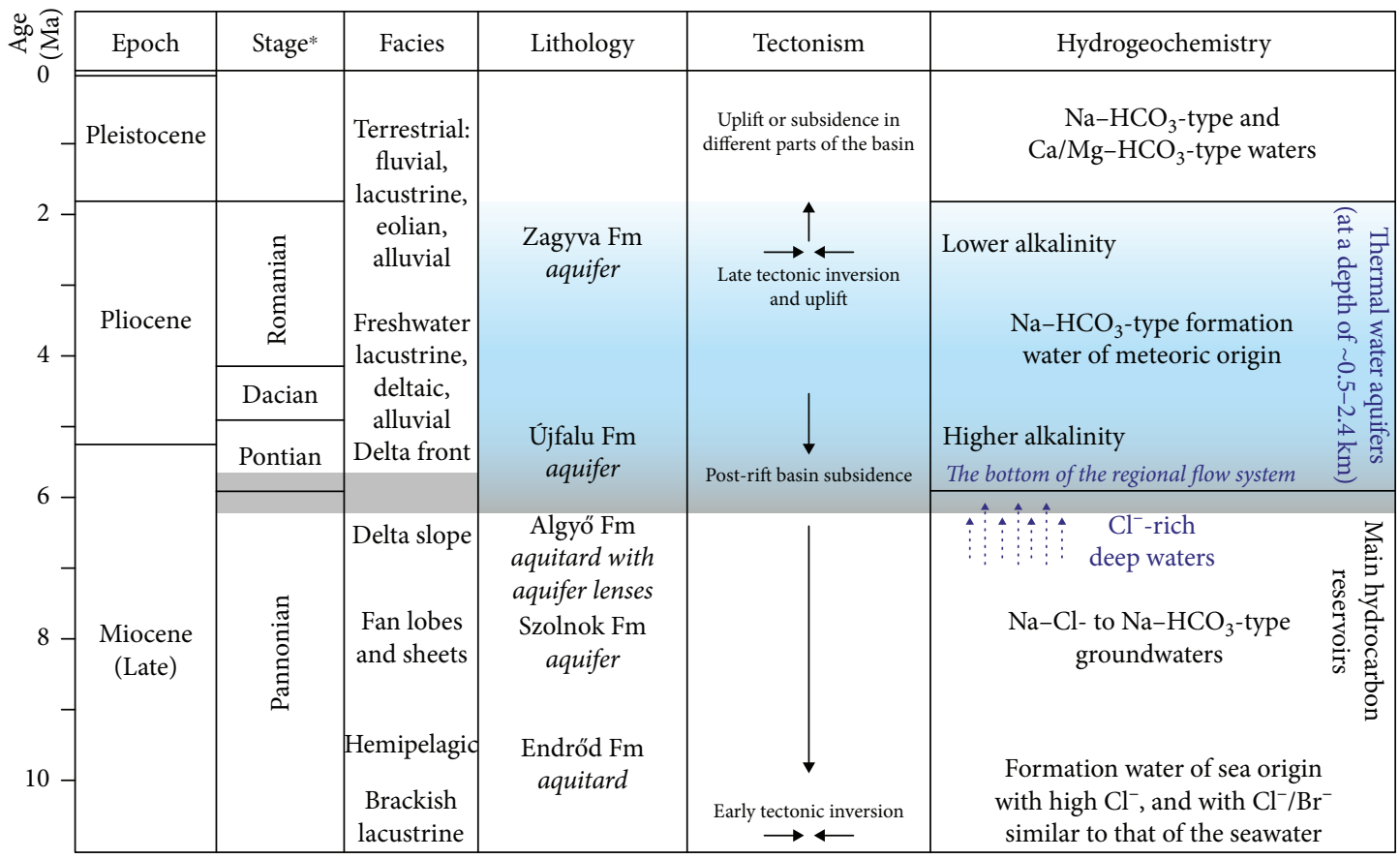

FIGURE 5: Summarized geological and geochemical information for the studied aquifers $[9,14-18,25,28-30]$. Thermal water aquifers are indicated by a blue bar. Gray rectangle indicates the estimated bottom of a regional flow system (Pannonian/Pontian boundary) [9]. Note: hydrogeochemical interpretations do not reflect the deposition of diachronous and laterally variable formations. Additionally, the Pannonian Basin is regarded as a nonuniform multilayer flow system in this conception. Abbreviation: Fm $=$ Formation. ${ }^{*}$ Central Paratethys [25].

will form but corrosion cannot happen, whereas if it is more than 6.8 , the water is aggressive [41].

Selected and representative scale-fragment samples from both study sites were investigated via mineralogical and petrographic methods. A total number of 20 mineral precipitates were collected for this study. Scales were sampled from different sections of the geothermal cascade system in Ujszeged district, suffering from problems with accumulation of carbonate material formed inside pipes (substrate material: carbon steel, standard number St37.0), especially near the buffer tank (samples G-03 and G-04), and inside production facilities such as interior surfaces of buffer tank, water filtration systems (coarse: $3 \mathrm{~mm}$; fine: $80 \mu \mathrm{m}$ ), and pumps (e.g., pump gland, pump blades, and filters; substrate material: acid-proof steel, alloying elements: $\mathrm{Cr}, \mathrm{Ni}$; standard number MSZ KO33) in the engine room (samples G-05-G09, G-11, G-23-G-30). Regarding the other cascade system (downtown), scale samples were recovered from pipes between the wellhead and the buffer tank (sample G-10). The carbonate scale samples were embedded in epoxy resin, cut, and polished at the Department of Mineralogy, Geochemistry and Petrology, University of Szeged, to obtain standard petrographic thin sections.

In order to provide a more detailed petrography, besides the standard thin section microscopy, fluorescence and CL (as described above) microscopy were also carried out. Micropetrography and fluorescence microscopy was performed using an Olympus BX-41 microscope equipped with a highpressure $\mathrm{Hg}$ lamp and filter sets for blue-violet (400-440 nm) and ultraviolet $(360-370 \mathrm{~nm})$ excitation. Additionally, bulk mineralogical composition of representative scale samples was also determined using XRPD described below in detail.

3.2. Methodology of XRPD Measurements for Rock and Scale Characterization. Determination of the bulk mineralogical composition and characterization of the separated $<2 \mu \mathrm{m}$ grain size (clay) fraction of 10 core samples from the well $\mathrm{H}-$ 1 were made by XRPD. Homogeneous rock chips were grounded and pulverized in an agate mortar $(<2$ min grinding time per sample). Bulk mineralogy of the fabric-selected and powdered scale samples, corresponding to the macroscopic features (e.g., color, zonation), was also determined. About 10 grams of representative scale samples was dissolved in diluted acetic acid ( $10 \mathrm{vol} \%$, for $24 \mathrm{~h}$ at room temperature) in order to characterize the insoluble residue. The representative samples were measured by a Rigaku Ultima IV X-ray diffractometer using a rotating sample holder (instrumental parameters: Bragg-Brentano geometry, $\mathrm{CuK} \alpha$ radiation, graphite monochromator, proportional counter, divergence, and detector slits of $2 / 3^{\circ}$ at $50 \mathrm{kV} / 40 \mathrm{~mA}$ from 3 to $70^{\circ} 2 \theta$ with goniometer step rate $1^{\circ} / \mathrm{min}$ and step width $0.05^{\circ}$ ) at the Department of Mineralogy, Geochemistry and Petrology, University of Szeged. The qualitative evaluation of the XRPD spectra was made by Rigaku PDXL 1.8 software using the ICDD (PDF2010) database. Semiquantitative mineralogical composition was determined based on the reference intensity ratio (RIR) method. Composition of carbonate minerals was estimated using empirical curve between $d_{104}$ values and composition in the calcite-dolomite solid solution series [42]. Domain (crystallite) size of the scale-forming material was calculated 
TABLE 1: Mineralogical composition of the studied bulk rock samples and separated clay fractions.

\begin{tabular}{|c|c|c|}
\hline & Major components $(\sim$ mass $\%)$ & Minor components ( mass\%) \\
\hline Sand-rich samples (bulk) & $\mathrm{q}(20-50), 10 \mathrm{~A}(10-60)$, dol $(5-20)$ & $\begin{array}{l}\mathrm{cal}(\operatorname{tr}-10), 14 \mathrm{~A}(5-10) \\
\mathrm{kf}(\operatorname{tr}), \mathrm{pl}(\operatorname{tr}-10), 7 \mathrm{~A}(\mathrm{tr})\end{array}$ \\
\hline Pelitic samples (bulk) & $\begin{array}{l}\text { 10A (10-60), q (20-40), 7A (tr-20), } \\
\text { 14A (tr-20), dol (5-30), pl (tr-20) }\end{array}$ & $\mathrm{cal}(\operatorname{tr}-10), \mathrm{kf}(\operatorname{tr})$, pyr $(\operatorname{tr})$ \\
\hline Sand-rich samples (clay fraction) & $10 \mathrm{~A}(30-70), \mathrm{chl}(20-60)$ & $\begin{array}{l}\text { 7A (5-10), sm (tr-10), } \\
\text { q (tr), cal (tr), dol (tr) }\end{array}$ \\
\hline Pelitic samples (clay fraction) & 10A (40-80), chl (10-40), 7A (5-20) & $\begin{array}{c}\text { sm }(5-10), \mathrm{q}(\mathrm{tr}), \mathrm{cal}(\mathrm{tr}) \\
\text { dol (tr), pyr (tr) }\end{array}$ \\
\hline
\end{tabular}

Abbreviations: $14 \mathrm{~A}=14$ Ångström phase (chlorite \pm vermiculite \pm smectite); $10 \mathrm{~A}=10$ Ångström phase (illite \pm mica); $7 \mathrm{~A}=7$ Ångström phase (kaolinite); $\mathrm{cal}=$ calcite; $\mathrm{chl}=$ chlorite; $\mathrm{dol}=$ dolomite; $\mathrm{kf}=\mathrm{K}$-feldspar; $\mathrm{pl}=$ plagioclase feldspar; $\mathrm{pyr}=$ pyrite; $\mathrm{q}=$ quartz; sm=smectite \pm highly swelling mixed-layer illite/smectite; $\operatorname{tr}=$ trace amount.

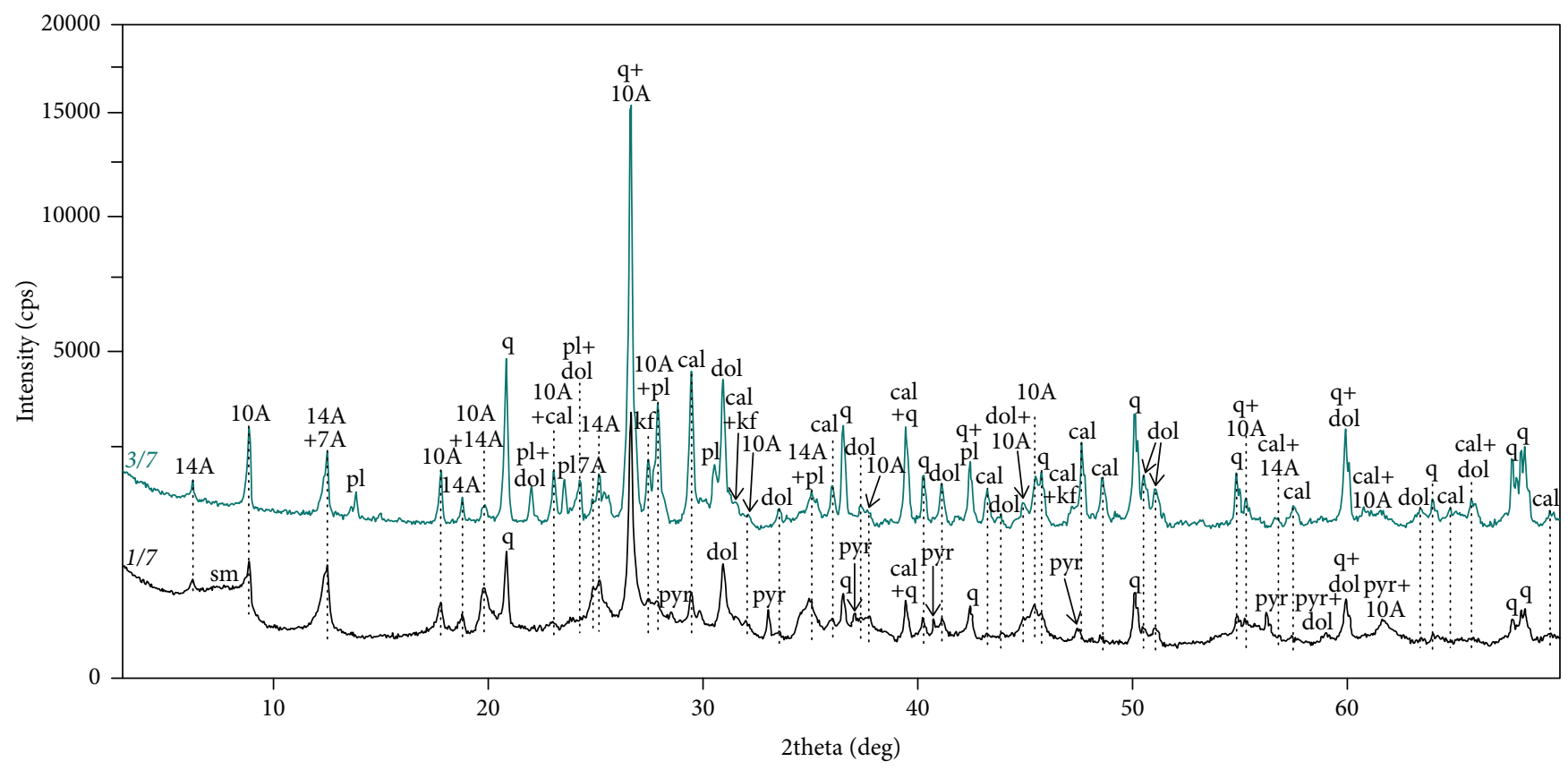

FIGURE 6: Typical XRPD patterns of representative bulk rock samples (sample 3/7: sandstone; sample 1/7: pyrite-bearing mudrock). Abbreviations: $14 \mathrm{~A}=14$ Ångström phase (chlorite \pm vermiculite \pm smectite); $10 \mathrm{~A}=10$ Ångström phase (illite \pm mica); 7A = 7 Ångström phase (kaolinite); cal=calcite; dol=dolomite; $\mathrm{kf}=\mathrm{K}$-feldspar; $\mathrm{pl}=$ plagioclase feldspar; pyr = pyrite; $\mathrm{q}=$ quartz; $\mathrm{sm}=\mathrm{smectite} \pm$ highly $\mathrm{swelling}$ mixed-layer illite/smectite.

by the Scherrer equation after removing the instrumental broadening [43]. The diffractograms made on samples of insoluble residue do not give evaluable peaks, suggesting a predominance of amorphous (or short range ordered) phases with undetermined composition. Consequently, no further discussion related to them is provided in this study.

Grain size separation for clay fraction analysis was achieved by repeated ultrasonic deflocculation and gravitational settling using Stokes' law. Highly oriented XRPD slides with $3 \mathrm{mg} / \mathrm{cm}^{2}$ density were prepared by repeated sedimentation of the separated clay fraction on a standard glass sample holder. Both air-dried and ethylene glycol-solvated preparations were scanned at $45 \mathrm{kV} / 35 \mathrm{~mA}$, from 2 to $50^{\circ} 2 \theta$ with goniometer step rate $1 \% \mathrm{~min}$ and step width $0.1^{\circ}$. Subsequently, the mounts were treated at 350 and $550^{\circ} \mathrm{C}$ and measured immediately after storage in a desiccator. Semiquantitative composition of the clay fraction was estimated following Moore and Reynolds' recommendation [44].

\section{Results and Discussion}

4.1. Core Description, Mineralogy, and Petrography. Using a hand lens together with a chart for visual estimation of grain size, the studied core samples can be subdivided into two groups, namely, sand-rich samples (very fine- to finegrained sandstones) and pelitic ones (mudrocks); rare coal seams also occur (Figures S1 and S2). The mineralogical composition of the studied reservoir rock groups is summarized in Table 1. Based on the bulk mineralogy (Table S1), mudrocks can be classified as siltstone, clayey marl, dolomitic marl, claystone (dolomitic and calcareous), and coal-bearing shale. In the lower part of well $\mathrm{H}-1$ 


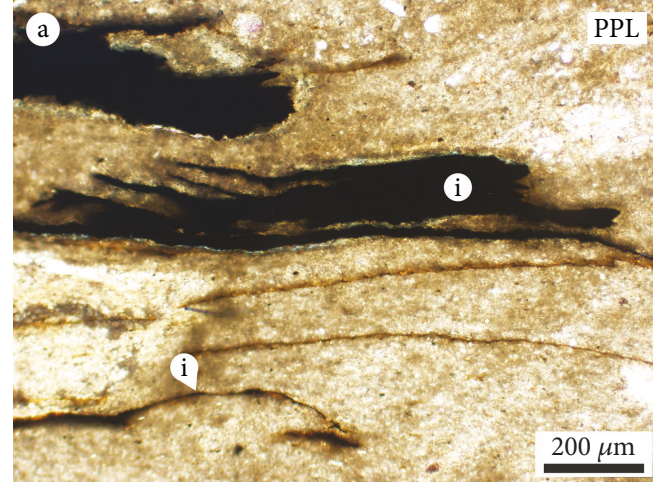

(a)

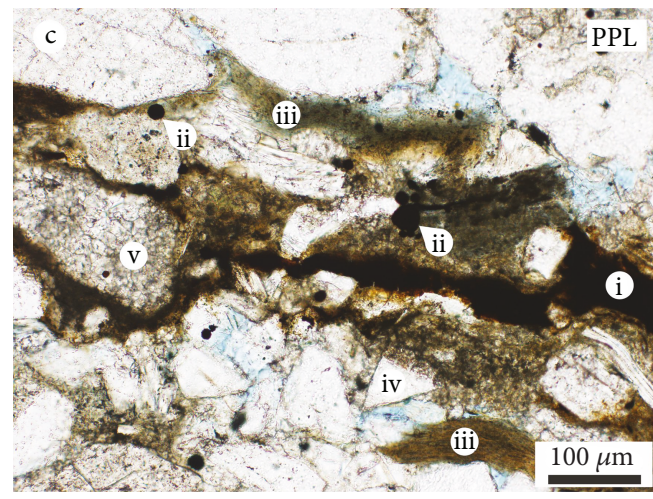

(c)

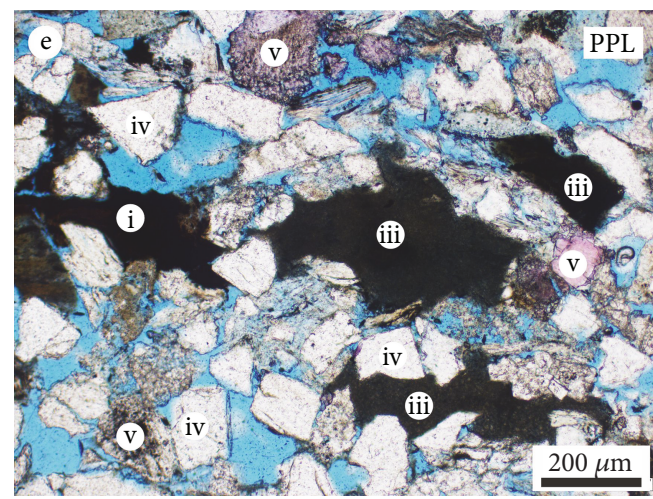

(e)

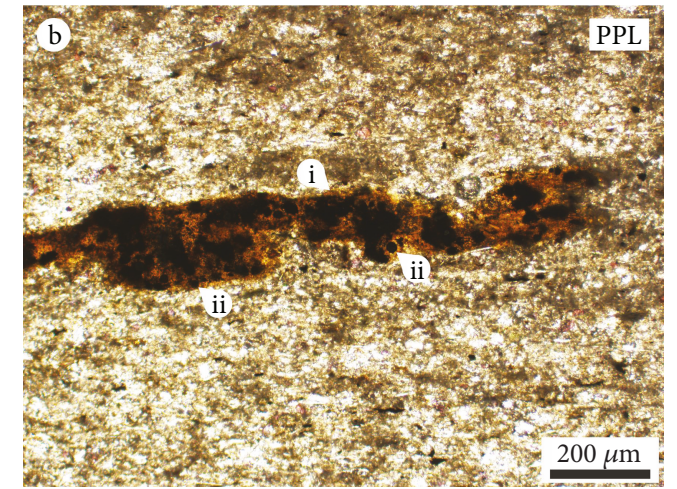

(b)

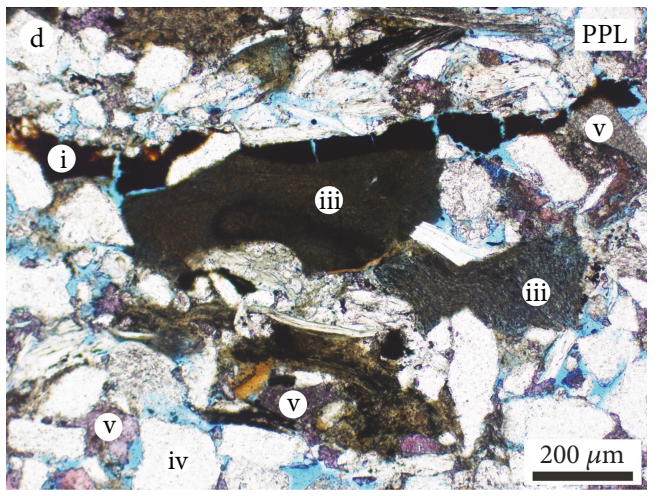

(d)

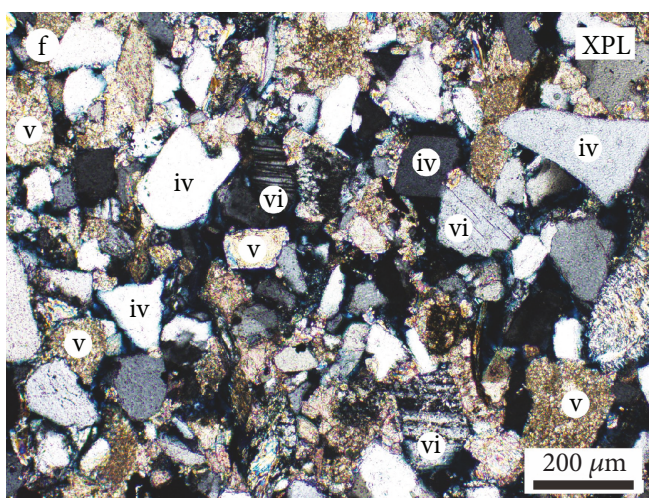

(f)

Figure 7: Micropetrographic characteristics of the studied mudrock and sandstone samples (a: 1/7; b: 1/10; c-e: 1/4; f: 1/3). (a, b) Textural features of the marl samples, including oriented organic matter fragments (i). Note enrichment of framboidal pyrites (ii, "black spots") in a close relationship with organic matter. (c-f) Silt- to sand-sized detrital grains together with organic matter (i) seams and reworked mudrock (iii) fragments in sandstones. Intergranular pores are filled by blue epoxy resin. Dominant framework grains: quartz (iv), carbonate lithics (v), and plagioclase feldspar (vi). Abbreviations: $\mathrm{PPL}=$ plane polarized light; XPL $=$ crossed polars.

$(\sim 1700 \mathrm{~m})$, the mudrocks contain a sparse macrofauna (thin shells of Paradacna abichi, Sándor Gulyás pers. comm.), reflecting brackish water and delta slope depositional facies (Figure S3).

The mineralogical composition of the bulk rock samples is quite similar, but some differences appear in the relative abundances of the phases (Figure 6). Generally, quartz, $10 \AA$ phases (illite \pm mica), and dolomite are the major components, whereas plagioclase (probably albitic), calcite, $14 \AA$ phases (chlorite \pm vermiculite \pm smectite or highly smectitic mixed-layer phase), $7 \AA$ phase (kaolinite), and K-feldspar are proved to be minor constituents. Some samples have extremely high amount of $10 \AA$ phases (illite \pm mica; up to 50-60\%) while others are very rich in carbonate minerals (calcite+dolomite $\approx 30-40 \%$ ) or plagioclase feldspar (1020\%). A single core sample (sample 1/7; Table S1) has a unique mineralogical character; it contains kaolinite as major constituent and has detectable pyrite content.

In order to determine the stoichiometry of the trigonal carbonate minerals, $d_{104}$ spacing was investigated on the bulk XRPD pattern of the samples. In the case of the calcite, the $d_{104}$ shows a rather uniform distribution with a value of 


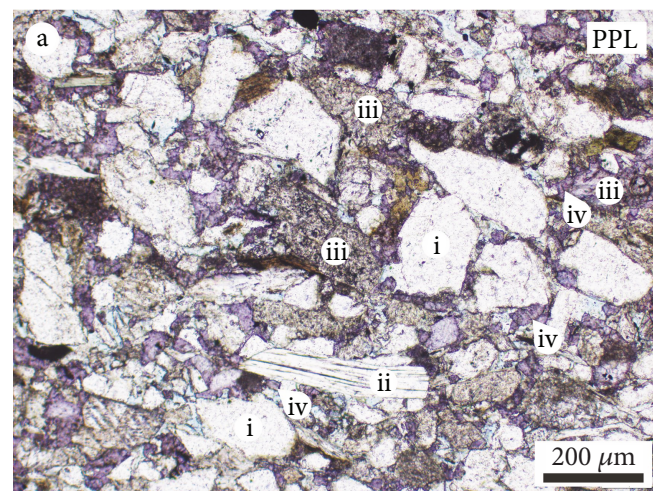

(a)

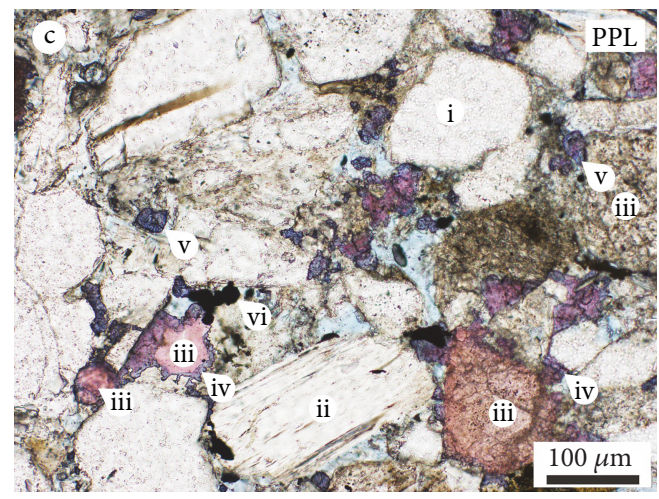

(c)

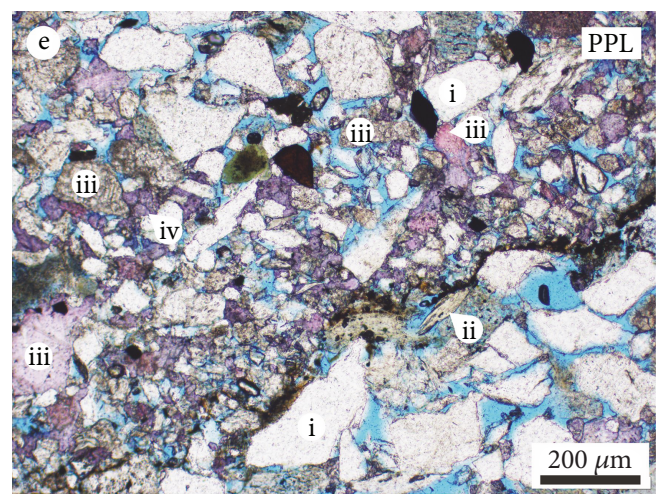

(e)

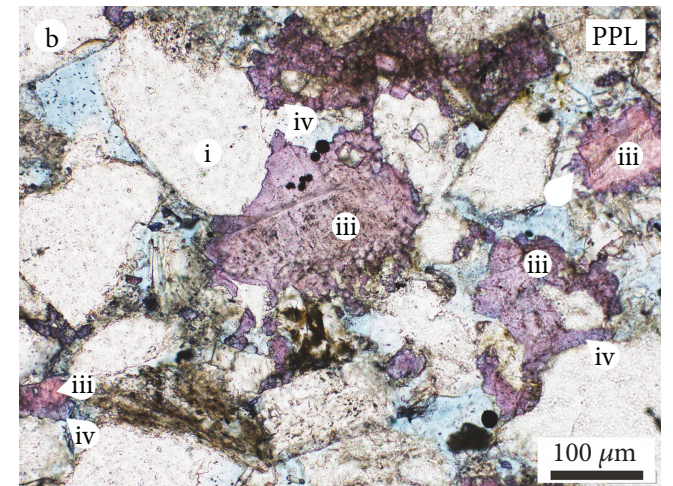

(b)

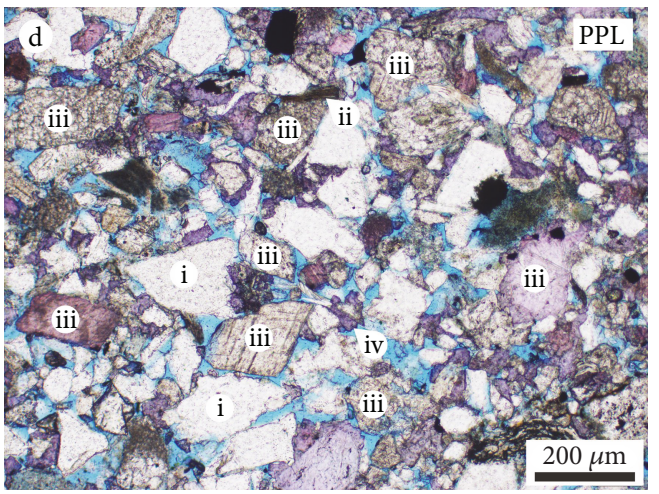

(d)

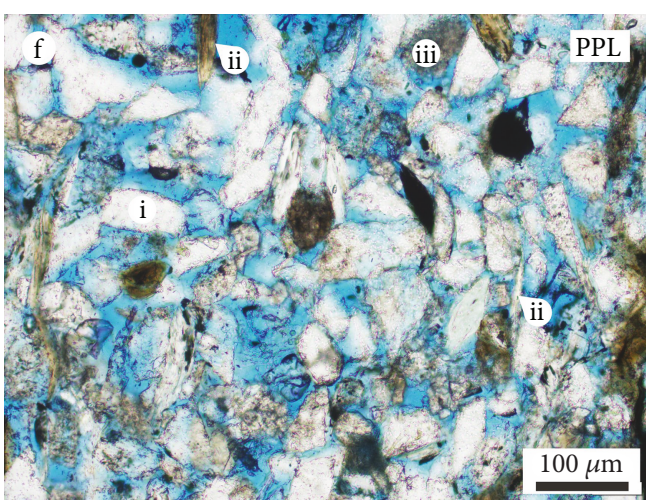

(f)

Figure 8: Micropetrographic characteristics of the studied sandstone and siltstone samples. (a-e) Pervasive to patchy cemented sandstones (a-c: $1 / 2 ; \mathrm{d}$ and e: $1 / 4 ; \mathrm{f}: 3 / 3$ ). Well-cemented zones can grade to poorly cemented zones over distances of a few tens of micrometers. Pores are filled by blue epoxy resin. Dominant framework grains: quartz (i), micas (ii), and carbonate lithics (iii, note: limestone clasts and detrital calcite crystals show red or pinkish color after staining but dolomite is unstained); dominant cements: Fe calcite (iv), ankerite (v), and framboidal pyrite aggregates (vi). (f) Poorly cemented sandy siltstone sample with locally high ( 20-25\%) porosity. Abbreviation: $\mathrm{PPL}=$ plane polarized light.

$3.030 \pm 0.001 \AA(n=10)$ which indicates a near stoichiometric composition with $\mathrm{a}<2-3 \%$ (molar) $\mathrm{MgCO}_{3}$ content. The $d_{104}$ values of the dolomite in the studied sediments similarly show near stoichiometric composition $(2.888 \pm 0.002 \AA$; $n$ =10) with a few percent $\mathrm{Mg}^{2+}$ deficiency (Table S2).

Regarding the clay fraction, the samples are predominated by illite \pm white mica. Nevertheless, the $14 \AA$ phase is a significant component of the clay fraction. It can be determined as chlorite due to its behavior after solvation with ethylene glycol and subsequent heat treatments. The kaolinite is generally a minor component, but two pelitic samples are relatively enriched in kaolinite (10-20\%), suggesting Kfeldspar hydrolysis. On the other hand, a highly expanding phase can be identified as smectite with $\sim 17 \AA$ base reflection, but a more accurate characterization and quantification cannot be achieved because of its diffuse peaks suggest poor crystallinity in most of the samples. Nevertheless, it is proved a minor constituent of the analyzed clay fractions with a 
proportion of up to $5-10 \%$. Trace amounts of quartz, calcite, and dolomite were detected in all analyzed samples as well (Figure S4).

The most striking micropetrographic feature of the mudrock samples is the common presence of sedimentary organic matter together with densely packed, spherical (framboidal) aggregates of tiny pyrite crystals (Figure 7). Petrographic analysis of the stained thin sections showed that the moderately to well-sorted sandstone samples are mineralogically immature. They are mixed carbonate-siliciclastic rocks and are composed of variable amounts of mono- and polycrystalline quartz grains, fresh to weakly altered feldspars (plagioclase and K-feldspar), micas (muscovite, biotite), chlorite, clays, and carbonate lithic grains (Figures 7 and 8). Metamorphic and volcanic rock fragments also appear in an inconsiderable amount. Detrital carbonate grains such as dolomite, limestone, and rare bioclast (e.g., bivalve shell) fragments are important components ( 10-25\%). Moreover, there are some accessory minerals such as zircon, tourmaline, rutile, garnet, and opaque grains. The polymictic and highly immature clast composition reflects the importance of local provenance (e.g., recycled detritus derived from erosion of intrabasinal basement highs) during the deposition of the Újfalu and Algyő sediments. Some previous studies [32, 37] have also shown carbonate (dolomite, limestone) source components in the underlying Upper Miocene formations (Szolnok and Endrőd).

It is noteworthy that in the studied core sections, a significant macroporosity $(\sim 5-25 \%)$ was observed in the sandstone and sandy siltstone samples; however, cementation can be pervasive locally. Reduced intergranular porosity is the most abundant type (Figures 7 and 8). No evidence of enlarged/oversized intergranular pores was found. Nevertheless, intragranular secondary porosity can also be found within partly leached feldspars. This result is consistent with the previous observations, suggesting that the effective porosity of the Pannonian reservoir sandstones can reach 22-25\% $[19,37]$.

The aforementioned mineralogical data reflect that kaolinite as a clay-mineral cement phase could occasionally form by feldspar alteration related to influx of meteoric water [12, $19,37]$; nevertheless, it is a minor component. Early diagenetic nonluminescent carbonate with variable iron content is the dominant cement in all of the studied siltstone and sandstone samples. Additionally, framboidal pyrite cement predated calcite precipitation also occurs. Carbonate staining reveals that most of the examined samples consist of ferroan calcite (Fe calcite) cements, showing mauve color, in a highly irregular distribution. Only a few pore-filling carbonate crystals show bluish color after staining, indicating the presence of minor amount of ferroan dolomite and/or ankerite as euhedral (rhomb-shaped) to subhedral crystals (Figure 8). Detrital carbonate grains serve as nuclei for calcite cement in most of the sandstones. The size of the cement crystals is controlled in part by the fabric of carbonate mineral in the detrital grains. Thus, micritic limestone/dolomite grains have microcrystalline calcite overgrowths in the first layer of cement, and crystals become larger away from the grains. On the other hand, single detrital crystals of spar have sparry overgrowths. Based on a previous study [37], ferroan calcite which is most probably one of the first authigenic phases formed is the volumetrically most significant cement type in the underlying Szolnok sandstone samples from the Algyő High.

During shallow burial diagenesis, pore waters undergo systematic changes [45]. When pore waters become significantly depleted in dissolved oxygen $(<0.5 \mathrm{ml} / \mathrm{l})$, a suboxic geochemical zone (including nitrate, manganese, and iron reduction subzones, successively) prevails. Additionally, in marine/brackish sediments, where the pore waters contain dissolved sulfate and are devoid of dissolved oxygen, bacterial sulfate reduction (BSR) can operate at shallow depths below the water-sediment interface to depths of a few hundred meters [32, 45, 46]. In the presence of reactive iron (e.g., Fe-bearing detrital minerals: biotite, chlorite; rock fragments), the precipitation of Fe sulfide as early diagenetic cement phase (i.e., framboidal aggregates of pyrite crystals) is a common process. Additionally, increased pore water alkalinity is recorded from organic-rich deposits influenced by BSR and pyrite formation [32, 45]. When pore waters are devoid of dissolved sulfide, excess $\mathrm{Fe}^{2+}$ can be incorporated into the carbonate lattice, forming ferroan calcite and/or ferroan dolomite/ankerite cement phases [45]. Consequently, the pore waters become significantly depleted in dissolved $\mathrm{Fe}^{2+}$ and sulfide.

4.2. Thermal Water Chemistry. Regarding thermal water sampling and major hydrochemical parameters, data for production and reinjection wells are listed in Table 2. All waters represent $\mathrm{Na}-\mathrm{HCO}_{3}$-type waters with variable TDS contents, ranging from 1670 to $6350 \mathrm{mg} / \mathrm{l}$. The investigated production wells exhibit high TDS (5430 and $6350 \mathrm{mg} / \mathrm{l}$, respectively), whereas the reinjection wells show lower TDS $(<4640 \mathrm{mg} / \mathrm{l})$. Sodium ion is the predominant cation, ranging from 450 to $1450 \mathrm{mg} / \mathrm{l}$. The $\mathrm{HCO}_{3}{ }^{-}$is the predominant anion, ranging from 1010 to $3180 \mathrm{mg} / \mathrm{l} ; \mathrm{Cl}^{-}$is the second highest anion, ranging from 27 to $420 \mathrm{mg} / \mathrm{l}$. Only groundwaters of the production wells exhibit measurable $\mathrm{SO}_{4}{ }^{2-}$ content (70 and $44 \mathrm{mg} / \mathrm{l}$, respectively), whereas dissolved and/or gaseous sulfide $\left(\mathrm{HS}^{-}, \mathrm{S}^{2-}\right.$ and $\mathrm{H}_{2} \mathrm{~S}$, respectively) content was not detected. Additionally, $\mathrm{pH}$ values range from 7.3 to 8.5 and the produced waters often show high dissolved organic matter (phenol index: 1852-2040 $\mu \mathrm{g} / \mathrm{l}$ ) and gas contents (total methane: $809-9581 / \mathrm{m}^{3}$; $\mathrm{CO}_{2}: 167-1991 / \mathrm{m}^{3}$ ).

Content of low to moderate amounts of alkaline earth metals $\left(\mathrm{Ca}^{2+}\right.$ : up to $11.2 \mathrm{mg} / \mathrm{l}, \mathrm{Mg}^{2+}$ : up to $\left.3.5 \mathrm{mg} / \mathrm{l}\right)$, chloride ion (up to $420 \mathrm{mg} / \mathrm{l}$ ), and sulfate ion (up to $70 \mathrm{mg} / \mathrm{l}$ ) reflects the presence of carbonate dissolution and also indicates brackish water in the pores $[45,46]$. The total Fe content in the thermal waters is relatively low $(<2.2 \mathrm{mg} / \mathrm{l})$, especially groundwaters of the production wells exhibit negligible $(<0.39 \mathrm{mg} / \mathrm{l}) \mathrm{Fe}$ content. Note that changes in thermal water chemistry such as decreasing alkaline earth metal concentrations together with increasing Fe content during system operational processes are purely related to man-made environmental conditions (e.g., carbonate scaling, corrosion, and biological processes). It is beyond the scope of this paper to discuss these technical influences in detail. 
TABLE 2: General hydrochemical properties of the investigated production (p) and reinjection (r) wells. Data for famous spas in Szeged are also shown for comparison.

\begin{tabular}{|c|c|c|c|c|c|c|c|c|}
\hline Well ID & B-415p & B-748 p & B-744 r & B-745 r & B-746 r & B-747 r & Anna well & Dóra II well \\
\hline Bottom depth (m) & 1999 & 1937 & 1396 & 1750 & 1740 & 1225 & 944 & 1706 \\
\hline Depth of screens (m) & $1727-1914$ & $1733-1878$ & $1112-1381$ & $1636-1741$ & $1519-1710$ & $1012-1150$ & n.d. & n.d. \\
\hline Number of filtered sections & 6 & 3 & 5 & 3 & 3 & 4 & n.d. & n.d. \\
\hline Effluent water temperature $\left({ }^{\circ} \mathrm{C}\right)$ & 79.8 & 76.9 & 55.7 & 75.6 & 64.5 & 54.9 & 52 & 80 \\
\hline Water yield $\left(\mathrm{m}^{3} / \mathrm{h}\right)$ & 39 & 54 & 56 & 35 & 78 & 72 & n.d. & n.d. \\
\hline \multicolumn{9}{|l|}{ Dissolved ions (mg/l) } \\
\hline $\mathrm{Na}^{+}$ & 1450 & 1420 & 1270 & 870 & 830 & 450 & 350 & 830 \\
\hline $\mathrm{K}^{+}$ & 18.2 & 19.5 & 15.3 & 10.8 & 8.5 & 3.4 & 2.2 & 8.3 \\
\hline $\mathrm{Li}^{+}$ & 0.24 & 0.26 & 0.15 & 0.16 & 0.12 & 0.02 & n.d. & 0.13 \\
\hline $\mathrm{NH}_{4}^{+}$ & 20.8 & 23.3 & 15.2 & 17.6 & 18.0 & 3.0 & 1.7 & 49.0 \\
\hline $\mathrm{Ca}^{2+}$ & 10.1 & 11.2 & 1.5 & 5.0 & 6.5 & 6.4 & 2.1 & 8.9 \\
\hline $\mathrm{Mg}^{2+}$ & 3.2 & 3.5 & 1.2 & 1.7 & 1.9 & 2.8 & 1.7 & 2.9 \\
\hline $\mathrm{Fe}$ (total) & 0.39 & 0.07 & 0.17 & 2.20 & 0.96 & 1.69 & 0.17 & 0.35 \\
\hline $\mathrm{Cl}^{-}$ & 420 & 350 & 245 & 27 & 40 & 123 & 35 & 44 \\
\hline $\mathrm{Br}^{-}$ & 3.20 & 6.30 & 3.20 & 0.32 & 0.22 & 0.33 & n.d. & 0.26 \\
\hline $\mathrm{I}^{-}$ & 3.20 & 3.10 & 1.90 & 0.11 & 0.09 & 0.12 & 0.08 & 0.15 \\
\hline $\mathrm{F}^{-}$ & 2.90 & 2.30 & 2.00 & 3.00 & 4.00 & 1.38 & 1.20 & 2.60 \\
\hline $\mathrm{SO}_{4}{ }^{2-}$ & 70 & 44 & $<10$ & $<10$ & $<10$ & $<10$ & $<10$ & 25 \\
\hline $\mathrm{HCO}_{3}^{-}$ & 2870 & 3180 & 2500 & 2370 & 2280 & 1010 & 810 & 2196 \\
\hline TDS (mg/l) & 5430 & 6350 & 4640 & 3480 & 3210 & 1670 & 2809 & 3169 \\
\hline $\mathrm{pH}$ & 8.3 & 7.3 & 8.5 & 7.5 & 8.2 & 7.8 & 7.8 & n.d. \\
\hline Phenol index $(\mu \mathrm{g} / \mathrm{l})$ & 1852 & 2040 & 1600 & 1740 & 273 & $<5$ & n.d. & n.d. \\
\hline Total methane $\left(1 / \mathrm{m}^{3}\right)$ & 958 & 809 & 303 & 106 & 84 & 16 & n.d. & n.d. \\
\hline $\mathrm{CO}_{2}\left(1 / \mathrm{m}^{3}\right)$ & 167 & 199 & 5 & 72 & 38 & $<1$ & n.d. & n.d. \\
\hline LSI & 1.66 & 0.7 & 0.58 & 0.42 & 1.04 & 0.36 & -0.51 & - \\
\hline RSI & 4.98 & 5.9 & 7.34 & 6.65 & 6.12 & 7.07 & 8.82 & - \\
\hline
\end{tabular}

Abbreviations: n.d. = no data; TDS = total dissolved solids; LSI = Langelier Stability Index; RSI = Ryznar Stability Index [41].

TABLE 3: Temporal changes of selected hydrochemical parameters in the geothermal system of Ujszeged district (well B-748).

\begin{tabular}{|c|c|c|c|c|c|c|c|c|}
\hline Date & Water yield $\left(\mathrm{m}^{3} / \mathrm{h}\right)$ & Temperature $\left({ }^{\circ} \mathrm{C}\right)$ & $\mathrm{pH}$ & TDS (mg/l) & $\mathrm{HCO}_{3}{ }^{-}(\mathrm{mg} / \mathrm{l})$ & $\mathrm{Ca}^{2+}(\mathrm{mg} / \mathrm{l})$ & LSI & RSI \\
\hline 19.10 .2017 & 5 & 34.6 & 7.75 & 4272 & 2501 & 6.66 & 0.10 & 7.55 \\
\hline 20.10 .2017 & 25 & 52.9 & 8.24 & 4100 & 3184 & 9.25 & 1.17 & 5.90 \\
\hline 21.10 .2017 & 35 & 74.5 & 8.43 & 4360 & 2251 & 8.32 & 1.53 & 5.38 \\
\hline 22.10 .2017 & 45 & 79.4 & 8.15 & 4340 & 2135 & 8.29 & 1.30 & 5.55 \\
\hline 24.10 .2017 & 55 & 71.7 & 8.43 & 4070 & 2147 & 8.02 & 1.45 & 5.54 \\
\hline 26.10 .2017 & 60 & 74.8 & 8.32 & 3980 & 2251 & 7.88 & 1.40 & 5.52 \\
\hline 23.01 .2018 & 62 & 91.4 & 8.21 & 3417 & 2561 & 6.90 & 1.56 & 5.09 \\
\hline 01.03 .2018 & 70 & 92.6 & 8.32 & 3405 & 2808 & 6.80 & 1.73 & 4.86 \\
\hline 11.04 .2018 & 54 & 91.6 & 8.32 & 3340 & 2697 & 6.00 & 1.64 & 5.03 \\
\hline
\end{tabular}

Abbreviations: TDS = total dissolved solids; LSI = Langelier Stability Index; RSI = Ryznar Stability Index [41] .

Interestingly, both production wells of the Szeged Geothermal Systems have relatively high-salinity thermal waters (TDS $>5 \mathrm{~g} / \mathrm{l}$ ) which support their scaling potential. Based on the hydrostratigraphic position of the targeted Ujfalu aquifer, these values are significantly higher than the expected ones (2-4 g/l). Obviously, all of the screened layers between $\sim 1700$ and $1900 \mathrm{~m}$ produce thermal water with moderate to high scaling ability because of the high bicarbonate concentration (up to $3180 \mathrm{mg} / \mathrm{l}$ ) and relatively high TDS values (up to $6350 \mathrm{mg} / \mathrm{l}$ ). Based on LSI results, except for Anna well, waters tend to be scale forming. On the other hand, RSI values range from $\sim 5$ to 9 (Table 2 ). For production wells of the studied cascade systems, relatively low RSI values $(<6.2)$ also reflect that scale will form, whereas RSI 


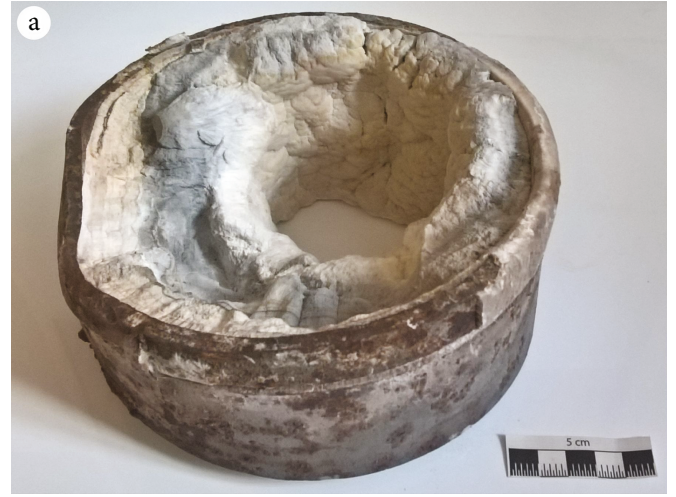

(a)

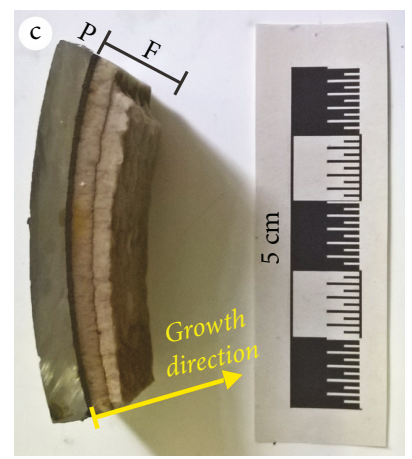

(c)

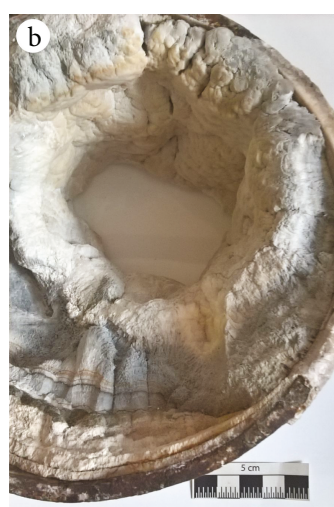

(b)

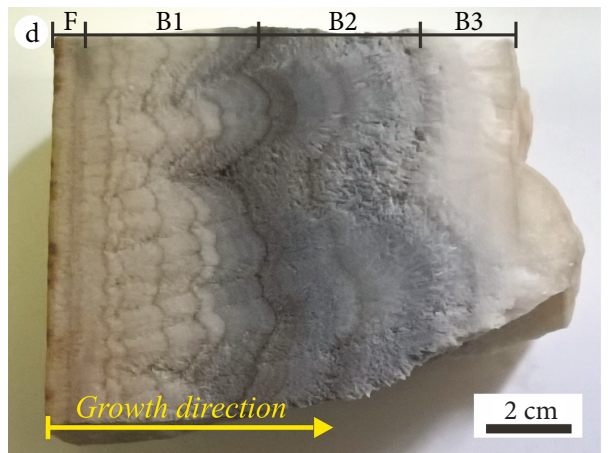

(d)

FIGURE 9: Thick carbonate scale samples from the Ujszeged geothermal cascade system sampled from a pipe between the production well and the buffer tank. (a, b) Macroscopic images of the sample G-03 (total length of the scale bar: $5 \mathrm{~cm}$ ). (c) Outer part of the sample G-03, showing a fibrous (F) morphology. Substrate material (pipe, P): carbon steel. (d) Inner part of the sample G-03, showing a complex morphology with fibrous (F) to botryoidal (B1 to B3) zones. Note: B1/B2 boundary (an intermittent brownish stained layer) separates seasonal (annual) operational rhythms. Fine lamination represents effects related to the periodical (weekly or daily) operational phases.

data for two reinjection wells together with the value for Anna well indicate an aggressive water, so corrosion could be significant. Relatively high chloride content (up to $420 \mathrm{mg} / \mathrm{l}$ ), as a corrosive constituent, could also promote steel corrosion and the products may constitute an attractive crystallization substrate for carbonate scales [6-8]. Results of a case study, however, indicate that strongly reducing redox conditions at $\mathrm{pH} \sim 6$, high sulfide, chloride, and gaseous $\mathrm{CO}_{2}$ contents together with high thermal fluid temperatures $\left(>100^{\circ} \mathrm{C}\right.$ in the aquifer) is necessary to promote efficient and rapid steel corrosion [6].

According to the temporal measurements data for the heating system of Újszeged, a decreasing tendency of TDS with some fluctuating pattern of the bicarbonate content is recognizable (Table 3) which suggests a diluted recharge of the thermal water aquifers in the screened sections. It is known for a long time now that meteoric flushing probably occurs downwards into the Szolnok Formation above the Algyő High where overlying Algyő Formation is sand dominated; additionally, synsedimentary faults can also act as pathways of fluid migration $[11,33,37]$. Therefore, it is possible that the aforementioned features reflect a contribution of meteoric water and/or might suggest a relationship with the lower TDS values of the reinjected waters (Table 2), corresponding to the man-made environmental conditions and disturbed natural hydrogeochemical equilibria.

Based on the short-term data in 2017, there is no significant correlation between the water yield and the water chemistry. Nevertheless, water sampled immediately after the off season (Table 3, first line) has the highest RSI value (7.55) that reflects to the high corrosion potential of the stagnant water in the production well. Contrarily in 2018, after $\sim 3-4$ months of operation, the TDS decreased ( 15\%), meanwhile the bicarbonate content fluctuated with some net increase $(\sim 10 \%)$. Additionally, a significant increase of thermal water temperature (from $\sim 75$ to $\sim 90^{\circ} \mathrm{C}$ ) was also observed. These features could reflect a high-temperature bicarbonate-rich water recharge from deeper aquifers (e.g., Triassic dolomite aquifers in the study area), corresponding to an open geochemical system. It is important to note that both calculated indices are in the range of calcite scale precipitation during the studied heating period. Furthermore, in 2018, low RSI data (RSI < 5.5 [41]) indicate that heavy scale will form which can also support a change of hydrogeochemical conditions during the heating season.

4.3. Mineralogical and Petrographic Characterization of the Scale Material with Genetic Aspects. The studied white to 


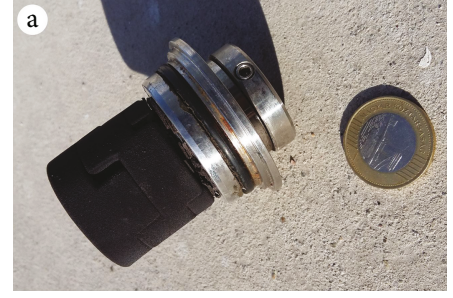

(a)

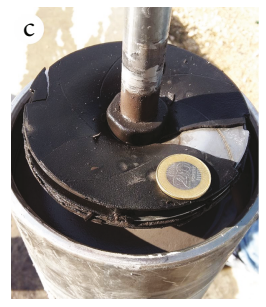

(c)

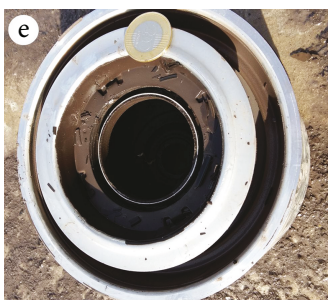

(e)

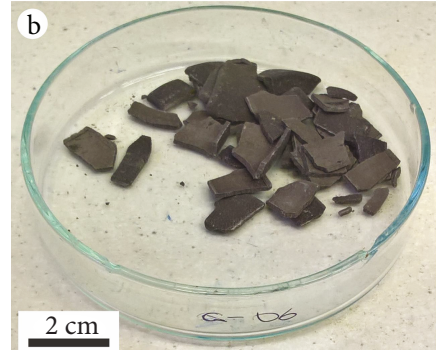

(b)

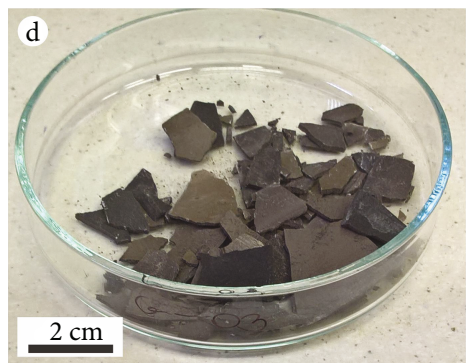

(d)

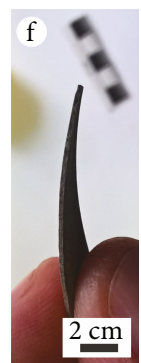

(f)

FIGURE 10: Scales from the Ujjszeged geothermal cascade system sampled in the engine room (interior surfaces of pumps). (a, b) Pump gland (sample G-06). (c, d) The last blade of the pump (sample G-08). (e,f) The first blade of the pump (sample G-09). Note: a coin (diameter: $28.3 \mathrm{~mm}$ ) is shown to provide scale.

grayish white-colored scale samples of up to $8 \mathrm{~cm}$ thickness in pipes between the Ujszeged production well and the buffer tank represent mineral precipitations up to 2 years, leading to a problematic reduction of inner diameters (Figure 9). They show compact (F, B1, and B3) and porous (B2) layers and thin macroscopic zonation of highly variable thicknesses, representing seasonal (annual) rhythmic growth patterns and event-like effects related to the periodical operational phases. These layers frequently show irregular, spherical boundaries and botryoidal-like textures (Figures 9 and S5). In the downtown system, the thick (up to $3 \mathrm{~cm}$ ) annual scale sample from the pipe between the production well and the buffer tank shows very similar characteristics (Figure S6). On the other hand, dominantly dark-colored scales from facilities (e.g., filters and pumps) in the engine room are typically thin (mm (range)), laminated, and fibrous deposits (Figure 10).

Mineralogically, all the studied representative scale samples show a uniform $\mathrm{Mg}$ calcite composition with $d_{104}=$ $3.012-3.016 \AA$, regardless of differences in color and morphology (Figure 11). According to the characteristic of the calcite 104 reflection, a 6-7\% (molar) $\mathrm{MgCO}_{3}$ content and a 500-600 A domain size can be estimated.

Microscopically, the thick calcite scale samples show a typical sequence of fine zones characterized by distinct fabrics and photoluminescent features. The generalized sequence typically begins with a thin (0.5 to $5 \mathrm{~mm}$ ) compact lamina composed of limpid, tightly packed fibrous or bladed crystals (F zone; Figures 12 and S6). Raggedness of the pipe surface serves as nuclei for the first tiny crystal, corresponding to the wall crystallization mechanism [8], and the following fibrous structure is probably the result of the limited growth competition [47]. Under CL microscope, this lamina is generally nonluminescent or shows a very dull, orange luminescence (Figure S6, b and c), suggesting reductive conditions during crystallization.

In the studied samples, the aforementioned first lamina is followed by several thicker zones (B1 to B3 zones; Figures 9 and 12). The scale in these zones is formed largely of complex calcite crystals that grew through the gradual addition of small subcrystals and are characterized by multiple level of 


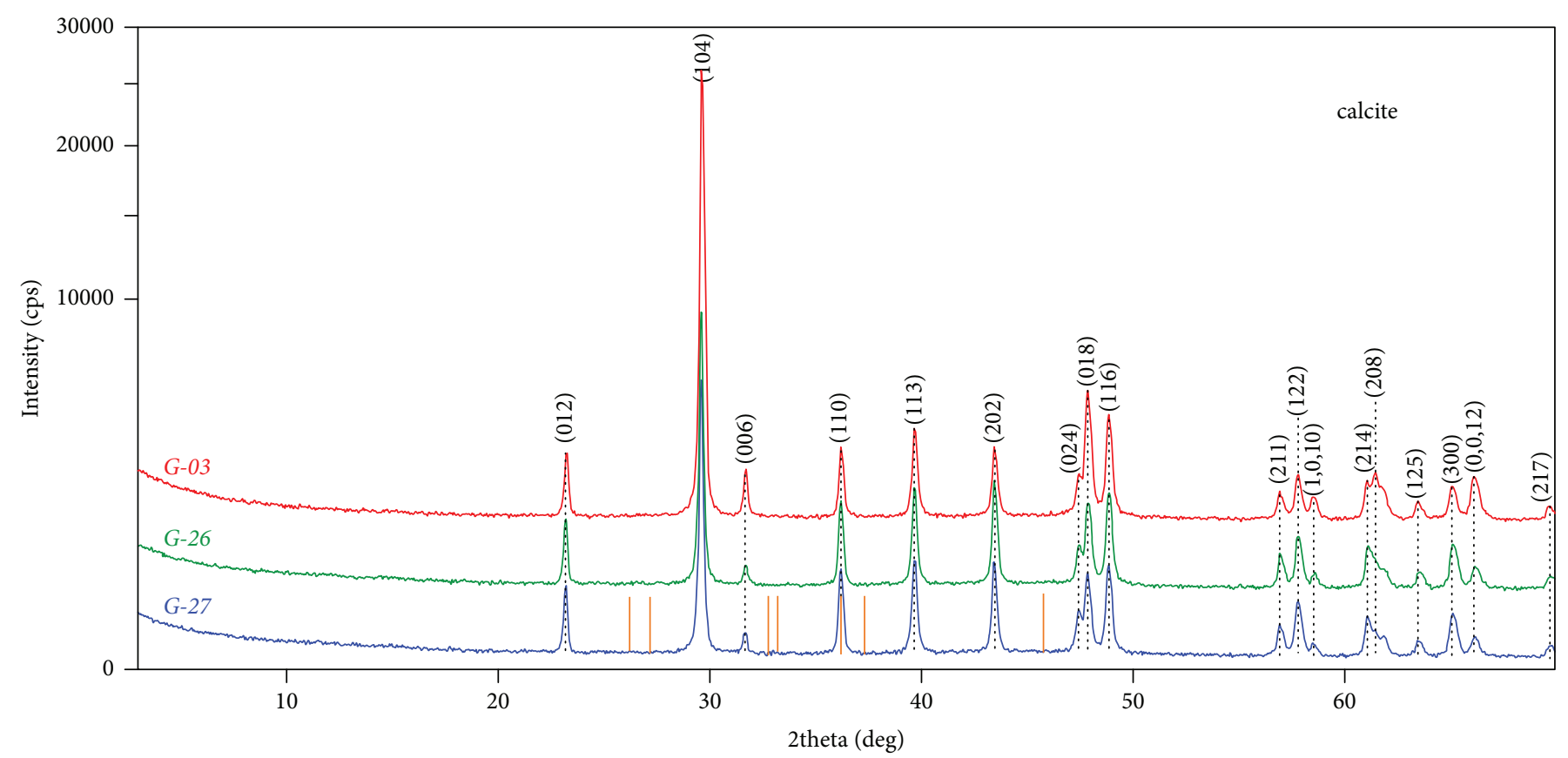

FIGURE 11: Typical XRPD patterns of representative scale samples (G-03: thick white scale, B1 zone; G-26 and G-27: thin dark brown scales formed inside pumps). Numbers in brackets at the peaks refer Miller indices. Orange lines indicate the diagnostic peaks of aragonite [44]. Note: aragonite (or another mineral phase) was not detected in the studied samples.

branching, corresponding to the feather dendrites which are types of noncrystallographic ones (with patterns that do not conform to the crystallographic directions $[48,49]$ ). Branches radiate outward and upward from the main branch and have an upward-widening character. Therefore, the inner surface of the scale displays a botryoidal-like texture (Figures 12 and S5-7). Consequently, the morphology of the studied dendrite crystals with their distinctive featherlike branching habit was controlled by the competition for growth space with neighboring crystals [47-49]. The zones of the dendritic and feather-like calcite generation generally display a dull bright orange luminescence under CL (Figure S7). Interestingly, some bushes in these zones have a relatively high internal porosity (Figure 12(e)) because of the branches are arranged in a somewhat looser network. In this part of the calcite scale, detrital minerals (mainly quartz, mica, and feldspar) also occur (Figure S8).

In the case of the thick scale sample from the Újszeged geothermal cascade system, representing two years of precipitation, the petrographic features in the sequence show seasonal (annual) repetition, and the sample can be subdivided into two main parts bounded by an intermittent brownish stained and bright luminescent biofilm (B1/B2 boundary; Figures 12(c) and $12(\mathrm{~d}))$. Based on the relative thicknesses of the annual zones (Figure 9(d)), a slightly increasing depositional rate can be suggested in the last heating season. This result is in accordance with the change of hydrogeochemical conditions discussed above. Additionally, the main structural zones can be subdivided into several subzones, depending mainly on the man-made environment related to the periodical (monthly/weekly or daily) operational phases. The boundary between these subzones is frequently represented by thin (few tens of micrometers) dark films without recognizable inner structure. Under CL, these films often show a bright red luminescence and have slight green fluorescence under violet-blue excitation, likely due to their organic content.

As far as the thin $(\sim 0.8-1.0 \mathrm{~mm})$, dark-colored scales precipitated on the facilities in the engine room are concerned, they display a relatively simple microtexture (Figure 13). They are composed of more or less limpid, but frequently turbid, tightly packed fibrous to bladed crystals. Additionally, porous dendritic texture was also observed. Two or three subzones can be distinguished in the thin scales with dark biofilm layers. Biofilms can exert either a passive or active function with respect to scale-forming processes [8]; however, it is out of scope to discuss their potential effects in detail.

The observed petrographic and photoluminescent features of the generalized growth zones can reflect to the seasonal (probably monthly/weekly) variability in geochemical parameters such as redox potential, $\mathrm{pH}$, and contamination by organic matter (e.g., biofilm forming). Manganese and Fe concentrations are the most important controlling factors in the cathodoluminescence of carbonates, and these elements have different redox potentials; therefore, the CL of carbonates can be useful for determining redox conditions during the carbonate precipitation [50,51]. As described above, in the initial stages of the scale precipitation, generally, limpid crystals were formed which are nonluminescent or show dull red CL, suggesting slightly reductive conditions. The later-precipitated cement overgrowths (feather dendrites), showing a brighter luminescence, indicate abundant $\mathrm{Mn}^{2+}$ content of the calcite crystals but unequivocally suggest that oxygen level was too high $(>0.5 \mathrm{ml} / \mathrm{l})$ to allow significant 


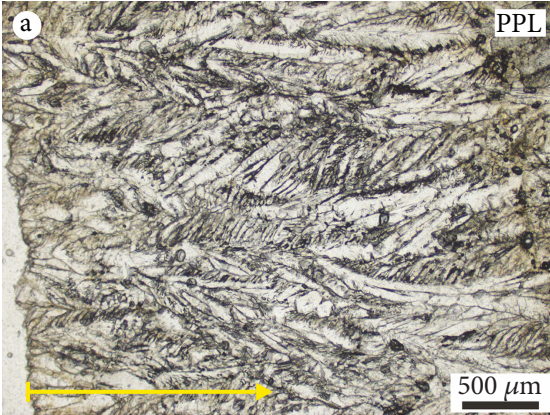

(a)

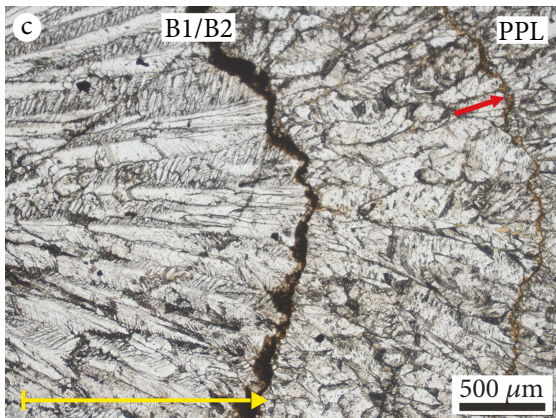

(c)

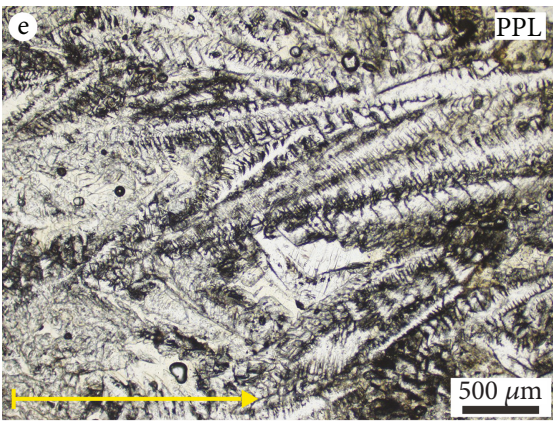

(e)

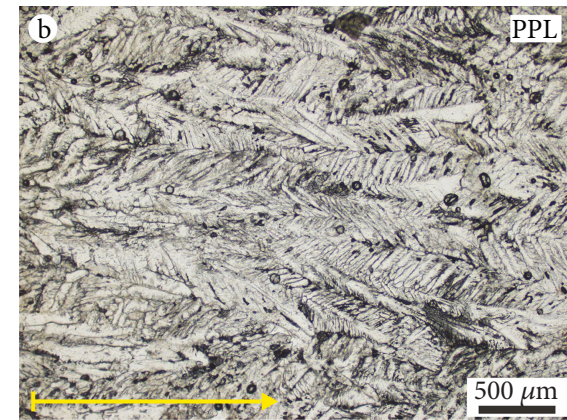

(b)

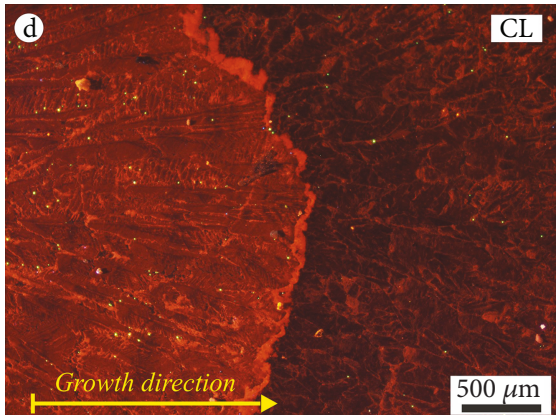

(d)

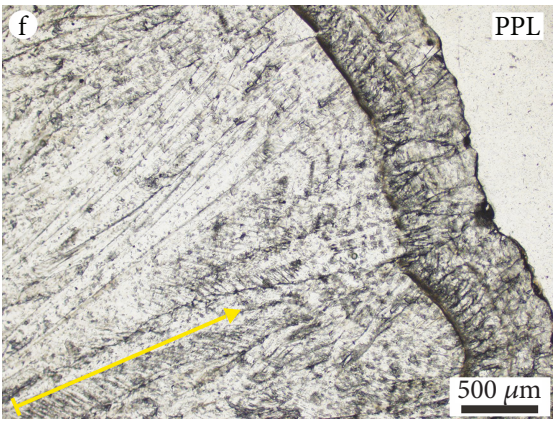

(f)

FIGURE 12: Inner structure of the thick carbonate scale (inner part of the sample G-03). The growth direction is marked by yellow arrows. (a) The scale precipitation begins with a thin $(<500 \mu \mathrm{m})$ compact lamina composed of limpid, tightly packed fibrous or bladed crystals (F zone), following a relatively compact dendritic-botryoidal zone (B1 zone). (b) Dendritic and feather-like calcite generation in the B1 zone. (c, d) Spherical growth zones made up of dendritic and bladed crystals and subdivided by a thin, bright luminescent film. Note: B1/B2 boundary (an intermittent brownish stained layer) separates annual operational rhythms. Red arrow indicates a very thin brownish stained layer without luminescence. (e) Feather-like dendrites in the porous B2 zone. (f) Contact of a limpid, tightly packed zone, made up of fibrous crystals and a fine, tightly packed zone with turbid crystals in the compact B3 zone. Abbreviations: PPL=plane polarized light; $\mathrm{CL}=$ cathodoluminescence.

$\mathrm{Fe}^{2+}$ to exist in aqueous solution which would quench the luminescence. It is important to note that some ingress of oxygen is possible in the buffer tank where degassing takes place (open system).

According to the previous papers [7, 48, 49], dendritic crystal growth has been attributed to the combined effects of parameters such as temperature, the presence of various (inorganic/organic) impurities, or the supercooling of a fluid, leading to high levels of supersaturation and subsequent rapid precipitation. Such crystals form through both abiotic and biotic processes (e.g., the presence of microbes and their associated biofilms). Crystal growth can be very rapid: calcite dendrites can be produced in the laboratory in 2 min [48].
For $\mathrm{CaCO}_{3}$ dendrites, high levels of supersaturation induced by rapid degassing of $\mathrm{CO}_{2}$ from fluids with high $\mathrm{pCO}_{2}$ have commonly been the inferred conditions for dendritic crystal growth $[48,49]$.

Calcite dendrite crystals are important components of calcite travertine that forms around many hot springs (e.g., Iceland, Kenya, and New Zealand) [48]. Their natural waters are of $\mathrm{Na}-\mathrm{Ca}-\mathrm{HCO}_{3}$ composition (temperature: $60-99^{\circ} \mathrm{C} ; \mathrm{pH}$ : 6.7-9.0) with varying $\mathrm{Mg}^{2+}, \mathrm{SO}_{4}{ }^{2-}$, and $\mathrm{Cl}^{-}$content. Dendritic calcite precipitation was driven by rapid $\mathrm{CO}_{2}$ degassing of $\mathrm{CO}_{2}$-rich thermal water that is highly supersaturated with respect to $\mathrm{CaCO}_{3}$ at the time of precipitation. Furthermore, dissolved $\mathrm{Mg}$ could have a role in crystal morphogenesis resulted 


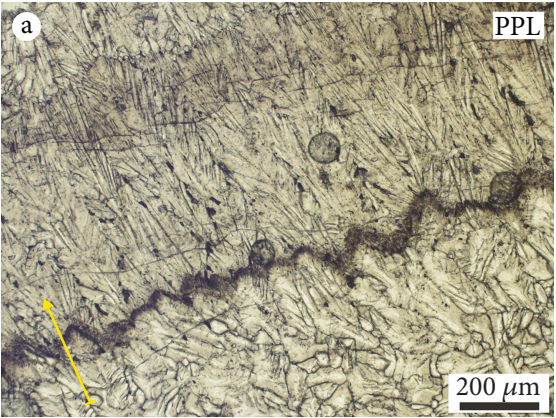

(a)

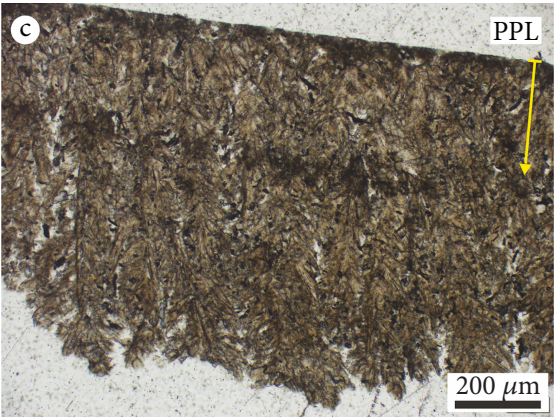

(c)

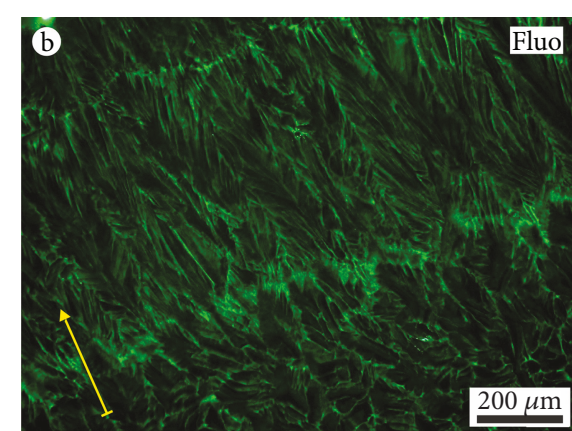

(b)

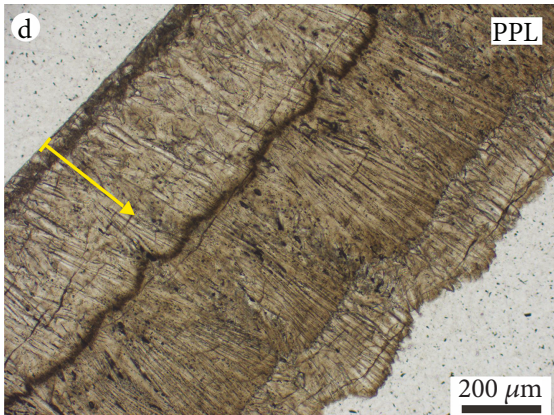

(d)

FIGURE 13: Inner structure of the thin carbonate scales. The growth direction is marked by yellow arrows. (a, b) Contact zone between two distinct growth zones, divided by an organic-rich, greenish fluorescent zone (sample G-06). (c) Thin dendritic carbonate scale sampled from the surface of a pump filter (sample G-07). (d) Thin fibrous and bladed carbonate scale sampled from the surface of a pump filter (sample G-08). Abbreviations: PPL = plane polarized light; Fluo = fluorescence.

in a wider range of crystal morphologies, and a change from single crystals to crystallite aggregates (precipitation of polycrystals) $[48,49]$. This explanation also seems applicable to the calcite dendrites in the studied scales. Similar to the thermal spring systems, available mineralogical and micropetrographic evidences suggest that the feather dendrites of low-Mg calcite were precipitated following rapid $\mathrm{CO}_{2}$ degassing of $\mathrm{CO}_{2}$-rich $\left(\mathrm{CO}_{2}: 200-300 \mathrm{~g} / \mathrm{m}^{3} ; \mathrm{HCO}_{3}{ }^{-}\right.$: up to $\left.3180 \mathrm{mg} / \mathrm{l}\right)$ thermal waters in the pipes close to the buffer tank where $\mathrm{CO}_{2}$ degassing was at its maximum in the studied systems.

Calcite crystal morphogenesis has commonly been linked to a "driving force" (e.g., increasing degree of supersaturation and/or supercooling) which is a conceptual measure of the distance of the growth conditions from equilibrium conditions [49]. It is important to note that dendrites are commonly precipitated under far-from-equilibrium conditions $[49,52]$, a fact that must be recognized in the interpretation of other analytical data such as stable isotope compositions. Additionally, on natural hot water, travertine precipitation clear evidence of low-temperature $\left(\sim 13-51^{\circ} \mathrm{C}\right)$ nonequilibrium feather calcite crystallization caused by high rate of $\mathrm{CO}_{2}$ degassing was also presented [52]. Micropetrographic analyses of the calcite dendrite crystals from scales strongly suggest that this phenomenon is equally true in both natural and man-made environments.

4.4. Water-Rock Interactions versus Thermal Water Quality. The key factors controlling porosity and permeability in reservoir sandstones are depositional characteristics such as grain size and sorting and diagenetic features such as cements and compaction-reduced primary and/or secondary porosity. Among the abovementioned factors, the distribution of mineral cements in aquifers is critical to the spatial variation of porosity and, therefore, permeability. On the other hand, dominant cement types can provide fruitful information about water-rock interactions regarding natural equilibrium conditions [32, 45, 46]. Our petrographic analysis revealed that pyrite and, finally, carbonate (dominantly $\mathrm{Fe}$ calcite) cements are the main diagenetic minerals in the studied geothermal reservoir rocks. The identified cement phases reveal that calcite and dolomite saturation states of thermal fluids are close to equilibrium in an oxygen-depleted aquifer [45]. This statement is supported by the nonluminescent (Fe-bearing) $\mathrm{Mg}$ calcite precipitation during the initial stage of the scale formation as described above.

Generally, the main sources of ions (calcium, magnesium, and bicarbonate) for carbonate cements are seawater, bioclasts, and carbonate lithic fragments [45]. In the studied Upper Miocene to Pliocene reservoir rocks, detrital carbonate grains are ubiquitous. Additionally, oxidation of local concentrations of organic matter in mudrocks, producing $\mathrm{CO}_{2}$ during early diagenesis $[45,46]$, can trigger carbonate precipitation as well. Framboidal pyrite aggregates reflect that the ancient pore water contained appreciable amounts of dissolved sulfate, so bacterial sulfate reduction could operate during early diagenesis, occurring a considerable increase in alkalinity $[32,45]$. In essence, the thermal water quality 
with a relatively high scaling potential in the study area reflects natural (geogen) environmental conditions in a mixed carbonate-siliciclastic system (instead of the pure end-member of siliciclastic aquifers).

The study area (e.g., the close vicinity of the town Szeged) has a nearly basement-high position (Figures 2 and 3). Uplifted basement highs in the Pannonian Basin have played an important role in the hydrologic history of the subbasins, providing conduits for fluid migration during basin evolution $[11,12,37]$. Temporal changes in chemistry and temperature of the produced thermal water during the heating season suggest the upflow of thermal water from an underlying aquifer. This water is characterized by somewhat decreased TDS and increased bicarbonate content, and it is important to note that both calculated indices (LSI and RSI) suggest a slightly increased scale-forming ability (Table 3). These chemical features might reflect to the hydrologic connection with a deep carbonate aquifer, such as the Triassic Szeged Dolomite Formation, which has basin-wide occurrences in the pre-Neogene basement [26, 27]. Additionally, previous modelling results suggest that the fractured basement highs in the Pannonian Basin govern heat transfer and fluid flow like a "hydrogeothermal chimney," resulting positive temperature anomaly at the top of the highs [13]. Continuous and/or temporal upflow of the basin-derived water is probably channeled by inherited extensional structures, neotectonic fault zones, and nontectonic faults above the Algyö High, as it was suggested by several authors in similar geological settings $[33,36]$.

\section{Conclusions}

In the Szeged Geothermal Systems (Hungary), having sandstone aquifers with dominantly $\mathrm{Na}-\mathrm{HCO}_{3}$-type thermal water, relatively high scale deposition rates have been observed. Analyses of the reservoir sandstones showed that they are mineralogically immature mixed carbonatesiliciclastic rocks with significant macroporosity. Their mineralogical composition shows rather high compositional variety but it is predominated by quartz, illite \pm mica, and dolomite, whereas plagioclase, calcite, chlorite, smectite, kaolinite, and $\mathrm{K}$-feldspar are generally minor constituents. Interestingly, detrital carbonate grains appear as important framework components (up to $\sim 20-25 \%$ ). During waterrock interactions, they could serve as a potential source of the calcium and bicarbonate ions, contributing to the elevated scaling potential. Therefore, this sandstone aquifer cannot be considered as a conventional siliciclastic reservoir. Additionally, in accompanying mudrocks with heterogeneous composition, a significant amount of organic matter also occurs, triggering $\mathrm{CO}_{2}$ producing reactions such as bacterial sulfate reduction in an early diagenetic system. Correspondingly, framboidal pyrite and ferroan calcite are the main cement minerals in all of the studied sandstone samples which can suggest that calcite saturation state of the thermal fluid is close to equilibrium in oxygen-depleted pore water.

Analysis of the dominant carbonate crystals in the scale can suggest that growth of the feather dendrites of low-Mg calcite was probably driven by rapid $\mathrm{CO}_{2}$ degassing of $\mathrm{CO}_{2}^{-}$ rich thermal water under far-from-equilibrium conditions, similarly to the hot spring systems (e.g., Iceland, Kenya, and New Zealand) [48]. Based on hydrogeochemical data and related indices for scaling and corrosion ability, the produced bicarbonate-rich thermal water has a significant potential for carbonate scaling which supports the aforementioned statement.

Taking into consideration our present knowledge of geological setting of the studied geothermal systems, the adjacent position to the Algyö High has crucial importance in the hydrologic system. First of all, temporal changes in chemical composition and temperature of the thermal water during the heating period can indicate upwelling fluids from a deep aquifer. Regarding the pre-Neogene basement, hydrologic contact with a Triassic carbonate aquifer (Szeged Dolomite Formation) might be reflected in the observed chemical features such as decreased TDS and increased bicarbonate content with high scale-forming ability. The proposed upflow of basin-derived water could be channeled by Neogene to Quaternary fault zones, including compaction effects creating fault systems above the elevated basement high.

Note that man-made influences also play a crucial role with regard to scale formation. For an advanced understanding of the controlling technical processes, therefore, further specific studies are needed in the future.

\section{Data Availability}

The hydrochemical, mineralogical, and petrographic data used to support the findings of this study are included within the article.

\section{Conflicts of Interest}

The authors declare that there is no conflict of interest regarding the publication of this paper.

\section{Acknowledgments}

The authors are thankful for the hydrochemical data and the scale and rock samples from the geothermal heating systems operating in Szeged owned by the Geothermal Service Provider Ltd., Hungary. This research was financially supported by the Economy Development and Innovation Operative Programme (GINOP-2.1.1-15-201600970). Regarding sandstone reservoir characterization, this research was also supported by the National Research, Development and Innovation Fund of Hungary (project Number K 108375).

\section{Supplementary Materials}

Supplementary Materials Figure S1: schematic lithologic logs of the investigated core sections (well H-1, Szeged, Hungary), showing the position of the studied samples. Figure S2: typical lithologic characters of the analyzed core sections (core diameter: $76 \mathrm{~mm}$ ). (a) Alternating fine-grained sandstones and siltstones with disseminated pyrite (brown spots), core \#3. (b) Alternating very fine-grained sandstones and mudrocks, core \#3. (c) Coal-bearing claystones, core \#1. 
Figure S3: bivalve shells in a clayey marl sample, core \#2. Note: the presence of thin shells of Paradacna abichi (arrow) reflects a delta slope depositional facies. Figure S4: typical XRPD patterns ( $<2 \mu \mathrm{m}$ fraction, highly oriented mount) of the studied core samples (sample 1/8). Abbreviations: ad: air-dry; eg: ethylene glycol solvated; 350: heat-treated at $350^{\circ} \mathrm{C}$; 550 : heat-treated at $550^{\circ} \mathrm{C}$; cal: calcite; chl: chlorite; dol: dolomite; ill \pm mu: illite \pm muscovite; k: kaolinite; q: quartz; sm: smectite \pm highly swelling mixed-layer illite/smectite. Figure S5: scanned overview images of a thin section prepared from the thick calcite scale (inner part of the sample G-03), showing a complex morphology with fibrous (F) to botryoidal (B1 to B3) zones. Note: B1/B2 boundary (an intermittent brownish stained layer) separates seasonal (annual) operational rhythms. Fine lamination represents effects related to the periodical (weekly or daily) operation phases. The growth direction is marked by a yellow arrow. Abbreviations: $\mathrm{PPL}=$ plane polarized light $\mathrm{XPL}=$ crossed polars. Figure S6: the studied annual scale sample (sample G-10) from the downtown geothermal cascade system sampled from a pipe between the production well and the buffer tank. (a) The calcite scale shows complex microscopic zonation of highly variable thicknesses. (b) and (c) Limpid, fibrous growth zone followed by a later zone composed of turbid dendritic skeletal crystals. Note that the carbonate precipitation began with the thin, limpid, and nonluminescent lamina (left) and was followed by a thick, luminescent, and more porous lamina with siliciclastic contamination (right). Abbreviations: $\mathrm{PPL}=$ plane polarized light $\mathrm{CL}=$ cathodoluminescence. Figure S7: dendritic crystal growth during scale formation (sample G10, downtown system). (a) and (b) Feather-like dendrites characterized by multiple level of branching. (c) and (d) Contact of a turbid zone, made up of dendritic crystals with bright CL and a limpid, tightly packed zone with dull luminescence. Abbreviations: $\mathrm{PPL}=$ plane polarized light; $\mathrm{CL}=$ cathodoluminescence. Figure S8: detrital minerals in the porous scale (sample G-03, B2 zone): muscovite (i), quartz (ii), and feldspar (iii). Abbreviations: $\mathrm{PPL}=$ plane polarized light; $\mathrm{XPL}=$ crossed polars; $\mathrm{CL}=$ cathodoluminescence. Table S1: mineralogical composition of the studied bulk rock samples and separated clay fractions. Abbreviations: $14 \mathrm{~A}=14$ Ångström phase (chlorite \pm vermiculite \pm smectite); $10 \mathrm{~A}=10$ Ångström phase (illite \pm mica); $7 \mathrm{~A}=7$ Ångström phase (kaolinite); cal=calcite; chl=chlorite; dol=dolomite; $\mathrm{sm}=$ smectite \pm highly swelling mixed-layer illite/smectite; $\mathrm{k}=$ kaolinite; $\mathrm{kf}=\mathrm{K}$-feldspar; $\mathrm{pl}=$ plagioclase feldspar; $\mathrm{pyr}=$ pyrite; $\mathrm{q}=$ quartz; $\mathrm{tr}=$ trace amount. Table S2: measured $d_{104}$ values and estimated composition of calcite and dolomite of the studied bulk rock samples. (Supplementary Materials)

\section{References}

[1] B. Norden, Ed., "Geothermal energy utilization in lowenthalpy sedimentary environments," in Scientific Technical Report STR11/06, Deutsches GeoForschungsZentrum GFZ, Potsdam, 2011.

[2] J. Szanyi and B. Kovács, "Utilization of geothermal systems in South-East Hungary," Geothermics, vol. 39, no. 4, pp. 357-364, 2010 .
[3] J. Szanyi, T. Medgyes, B. Kóbor, and E. Pál-Molnár, Technologies of Injection into Sandstone Reservoirs: Best Practices, Case Studies, GeoLitera Publishing House, Szeged, Hungary, 2015.

[4] T. Marković, A. Batres, I. Bobovečki et al., "Summary report on the evaluation case studies (D.5.3.1)," in Interreg Danube Transnational Programme, DARLINGe, 2018.

[5] M. Osvald, G. Maróti, B. Pap, and J. Szanyi, "Biofilm forming bacteria during thermal water reinjection," Geofluids, vol. 2017, Article ID 9231056, 7 pages, 2017.

[6] R. Boch, A. Leis, E. Haslinger et al., "Scale-fragment formation impairing geothermal energy production: interacting $\mathrm{H}_{2} \mathrm{~S}$ corrosion and $\mathrm{CaCO}_{3}$ crystal growth," Geothermal Energy, vol. 5, no. 1, 2017.

[7] R. Boch, J. Szanyi, A. Leis et al., "Geothermal carbonate scaling: forensic studies applying high-resolution geochemical methods," in European Geothermal Congress 2016 Strasbourg, France, 2016.

[8] R. Boch, A. Leis, A. Mindszenty et al., "Scaling forensics: evaluating geothermal production conditions from scales as chemical-sedimentary archives," in German Geothermal Congress GGC 2017 Munich, Germany, 2017.

[9] I. Varsányi, L. Ó. Kovács, and A. Bálint, "Hydraulic conclusions from chemical considerations: groundwater in sedimentary environments in the central part of the Pannonian Basin, Hungary," Hydrogeology Journal, vol. 23, no. 3, pp. 423-435, 2015.

[10] J. Tóth, "Hydraulic continuity in large sedimentary basins," Hydrogeology Journal, vol. 3, no. 4, pp. 4-16, 1995.

[11] J. Tóth and I. Almási, "Interpretation of observed fluid potential patterns in a deep sedimentary basin under tectonic compression: Hungarian Great Plain, Pannonian basin," Geofluids, vol. 1, no. 1, 36 pages, 2001.

[12] A. Juhász, T. M. Tóth, K. Ramseyer, and A. Matter, "Connected fluid evolution in fractured crystalline basement and overlying sediments, Pannonian Basin, SE Hungary," Chemical Geology, vol. 182, no. 2-4, pp. 91-120, 2002.

[13] I. Vass, T. M. Tóth, J. Szanyi, and B. Kovács, "Hybrid numerical modelling of fluid and heat transport between the overpressured and gravitational flow systems of the Pannonian Basin,” Geothermics, vol. 72, pp. 268-276, 2018.

[14] K. Korim, "Geological aspects of thermal water occurrences in Hungary," Geothermics, vol. 1, no. 3, pp. 96-102, 1972.

[15] I. Varsányi, J.-M. Matray, and L. Ó. Kovács, "Geochemistry of formation waters in the Pannonian Basin (Southeast Hungary)," Chemical Geology, vol. 140, no. 1-2, pp. 89-106, 1997.

[16] I. Varsányi, J.-M. Matray, and L. Ó. Kovács, "Hydrogeochemistry in two adjacent areas in the Pannonian Basin (Southeast-Hungary)," Chemical Geology, vol. 156, no. 1-4, pp. 2539, 1999.

[17] I. Varsányi, L. Ó. Kovács, Z. Kárpáti, and J.-M. Matray, "Carbon forms in formation waters from the Pannonian Basin, Hungary," Chemical Geology, vol. 189, no. 3-4, pp. 165-182, 2002.

[18] I. Varsányi and L. Ó. Kovács, “Origin, chemical and isotopic evolution of formation water in geopressured zones in the Pannonian Basin, Hungary," Chemical Geology, vol. 264, no. 1-4, pp. 187-196, 2009.

[19] M. Osvald, J. Szanyi, T. Medgyes, B. Kóbor, and A. Csanádi, "Geothermal energy developments in the district heating of Szeged," European Geologists, vol. 43, pp. 30-33, 2017. 
[20] G. Tari, P. Dövényi, I. Dunkl et al., "Lithospheric structure of the Pannonian Basin derived from seismic, gravity and geothermal data," Geological Society, London, Special Publications, vol. 156, no. 1, pp. 215-250, 1999.

[21] G. Tari and F. Horváth, "Alpine evolution and hydrocarbon geology of the Pannonian Basin: an overview," in The Carpathians and Their Foreland: Geology and Hydrocarbon Resources, J. Golonka and F. J. Picha, Eds., vol. 84, pp. 605618, AAPG Memoir, 2006.

[22] J. Haas and C. Péró, "Mesozoic evolution of the Tisza Megaunit," International Journal of Earth Sciences, vol. 93, no. 2, pp. 297-313, 2004.

[23] J. Haas, T. Budai, L. Csontos, L. Fodor, and G. Konrád, PreCenozoic Geological Map of Hungary 1:500 000, Hungarian Geological Institute, 2010.

[24] S. M. Schmid, D. Bernoulli, B. Fügenschuh et al., "The AlpineCarpathian-Dinaridic orogenic system: correlation and evolution of tectonic units," Swiss Journal of Geosciences, vol. 101, no. 1, pp. 139-183, 2008.

[25] L. Matenco and D. Radivojević, "On the formation and evolution of the Pannonian Basin: constraints derived from the structure of the junction area between the Carpathians and Dinarides," Tectonics, vol. 31, no. 6, 2012.

[26] I. Garaguly, B. Raucsik, A. Varga, and F. Schubert, "Középsőtriász dolomitok képződésének története és töréses deformációja a Szegedi-medence területén," Földtani Közlöny, vol. 147, no. 1, p. 39, 2017.

[27] I. Garaguly, A. Varga, B. Raucsik, F. Schubert, G. Czuppon, and R. Frei, "Pervasive early diagenetic dolomitization, subsequent hydrothermal alteration, and late stage hydrocarbon accumulation in a Middle Triassic carbonate sequence (Szeged Basin, SE Hungary)," Marine and Petroleum Geology, vol. 98, pp. 270-290, 2018.

[28] I. Magyar, D. Radivojević, O. Sztanó, R. Synak, K. Ujszászi, and M. Pócsik, "Progradation of the paleo-Danube shelf margin across the Pannonian Basin during the Late Miocene and Early Pliocene," Global and Planetary Change, vol. 103, pp. 168-173, 2013.

[29] O. Sztanó, P. Szafián, I. Magyar et al., “Aggradation and progradation controlled clinothems and deep-water sand delivery model in the Neogene Lake Pannon, Makó Trough, Pannonian Basin, SE Hungary," Global and Planetary Change, vol. 103, pp. 149-167, 2013.

[30] G. Juhász, G. Pogácsás, I. Magyar, and P. Hatalyák, “The Alpar canyon system in the Pannonian Basin, Hungary - its morphology, infill and development," Global and Planetary Change, vol. 103, pp. 174-192, 2013.

[31] K. Báldi, F. Velledits, S. Ćorić, V. Lemberkovics, K. Lőrincz, and M. Shevelev, "Discovery of the Badenian evaporites inside the Carpathian arc: implications for global climate change and Paratethys salinity," Geologica Carpathica, vol. 68, no. 3, pp. 193-206, 2017.

[32] A. Varga, V. Baranyi, B. Raucsik, and F. Schubert, “Az Endrődi Formáció kőzettani és palinológiai vizsgálata a Hódmezővásárhely-I fúrásban (Makói-árok) - őskörnyezeti és diagenezis-történeti értékelés," Földtani Közlöny, vol. 147, no. 1, p. $61,2017$.

[33] A. Balázs, I. Magyar, L. Matenco, O. Sztanó, L. Tőkés, and F. Horváth, "Morphology of a large paleo-lake: analysis of compaction in the Miocene-Quaternary Pannonian Basin," Global and Planetary Change, vol. 171, pp. 134-147, 2018.
[34] P. Dövényi and F. Horváth, "A review of temperature, thermal conductivity, and heat flow data from the Pannonian basin," in The Pannonian Basin: A Study in Basin Evolution, L. H. Royden and F. Horváth, Eds., vol. 45, pp. 195-233, AAPG Memoir, 1988.

[35] L. Lenkey, P. Dövényi, F. Horváth, and S. A. P. L. Cloetingh, "Geothermics of the Pannonian Basin, and its bearing on the neotectonics," EGU Stephan Mueller Special Publication Series, vol. 3, pp. 29-40, 2002.

[36] S. Simon, J. Mádl-Szőnyi, I. Müller, and G. Pogácsás, “Conceptual model for surface salinization in an overpressured and a superimposed gravity-flow field, Lake Kelemenszék area, Hungary," Hydrogeology Journal, vol. 19, no. 3, pp. 701-717, 2011.

[37] J. Mátyás, Diagenesis and Porosity Evolution of Neogene Reservoir Sandstones in the Pannonian Basin (Southeast Hungary), University of Bern, Institute of Geological Sciences, 1994.

[38] J. Pigott and D. Radivojevic, "Seismic stratigraphy based chronostratigraphy (SSBC) of the Serbian Banat Region of the Pannonian Basin," Open Geosciences, vol. 2, no. 4, 2010.

[39] B. Badics and I. Vető, "Source rocks and petroleum systems in the Hungarian part of the Pannonian Basin: the potential for shale gas and shale oil plays," Marine and Petroleum Geology, vol. 31, no. 1, pp. 53-69, 2012.

[40] J. A. D. Dickson, "Carbonate identification and genesis as revealed by staining," SEPM Journal of Sedimentary Research, vol. Vol. 36, 1966.

[41] E. Hoseinzadeh, A. Yusefzadeh, N. Rahimi, and H. Khorsandi, "Evaluation of corrosion and scaling potential of a water treatment plant," Archives of Hygiene Sciences, vol. 2, pp.41-47, 2013.

[42] F. Zhang, H. Xu, H. Konishi, and E. E. Roden, "A relationship between $\mathrm{d}_{104}$ value and composition in the calcite-disordered dolomite solid-solution series," American Mineralogist, vol. 95, no. 11-12, pp. 1650-1656, 2010.

[43] H. P. Klug and L. E. Alexander, X-Ray Diffraction Procedures, Wiley and Sons, London, United Kingdom, 1962.

[44] D. M. Moore and R. C. Reynolds, X-Ray Diffraction and the Identification and Analysis of Clay Minerals, Oxford University Press, Oxford, United Kingdom, 1997.

[45] S. Morad, "Carbonate cementation in sandstones: distribution patterns and geochemical evolution," in Carbonate Cementation in Sandstones, S. Morad, Ed., vol. 26, pp. 1-26, Special Publications of the International Association of Sedimentologists, 1988.

[46] C. A. J. Appelo and D. Postma, Geochemistry, Groundwater and Pollution, Second Edition, CRC Press, 2009, fourth corrected reprint.

[47] P. D. Bons, M. A. Elburg, and E. Gomez-Rivas, "A review of the formation of tectonic veins and their microstructures," Journal of Structural Geology, vol. 43, pp. 33-62, 2012.

[48] B. Jones, R. W. Renaut, R. B. Owen, and H. Torfason, “Growth patterns and implications of complex dendrites in calcite travertines from Lysuholl, Snaefellsnes, Iceland," Sedimentology, vol. 52, pp. 1277-1301, 2005.

[49] B. Jones, "Review of aragonite and calcite crystal morphogenesis in thermal spring systems," Sedimentary Geology, vol. 354, pp. 9-23, 2017.

[50] M. Pagel, V. Barbin, P. Blanc, and D. Ohnenstetter, Cathodoluminescence in Geosciences, Springer, Heidelberg, Germany, 2010. 
[51] E. E. Hiatt and P. K. Pufahl, "Cathodoluminescence petrography of carbonate rocks: a review of applications for understanding diagenesis, reservoir quality, and pore system evolution," Mineralogical Association of Canada Short Course, vol. 45, pp. 75-96, 2014.

[52] S. Kele, M. Özkul, I. Fórizs et al., "Stable isotope geochemical study of Pamukkale travertines: new evidences of lowtemperature non-equilibrium calcite-water fractionation," Sedimentary Geology, vol. 238, no. 1-2, pp. 191-212, 2011. 

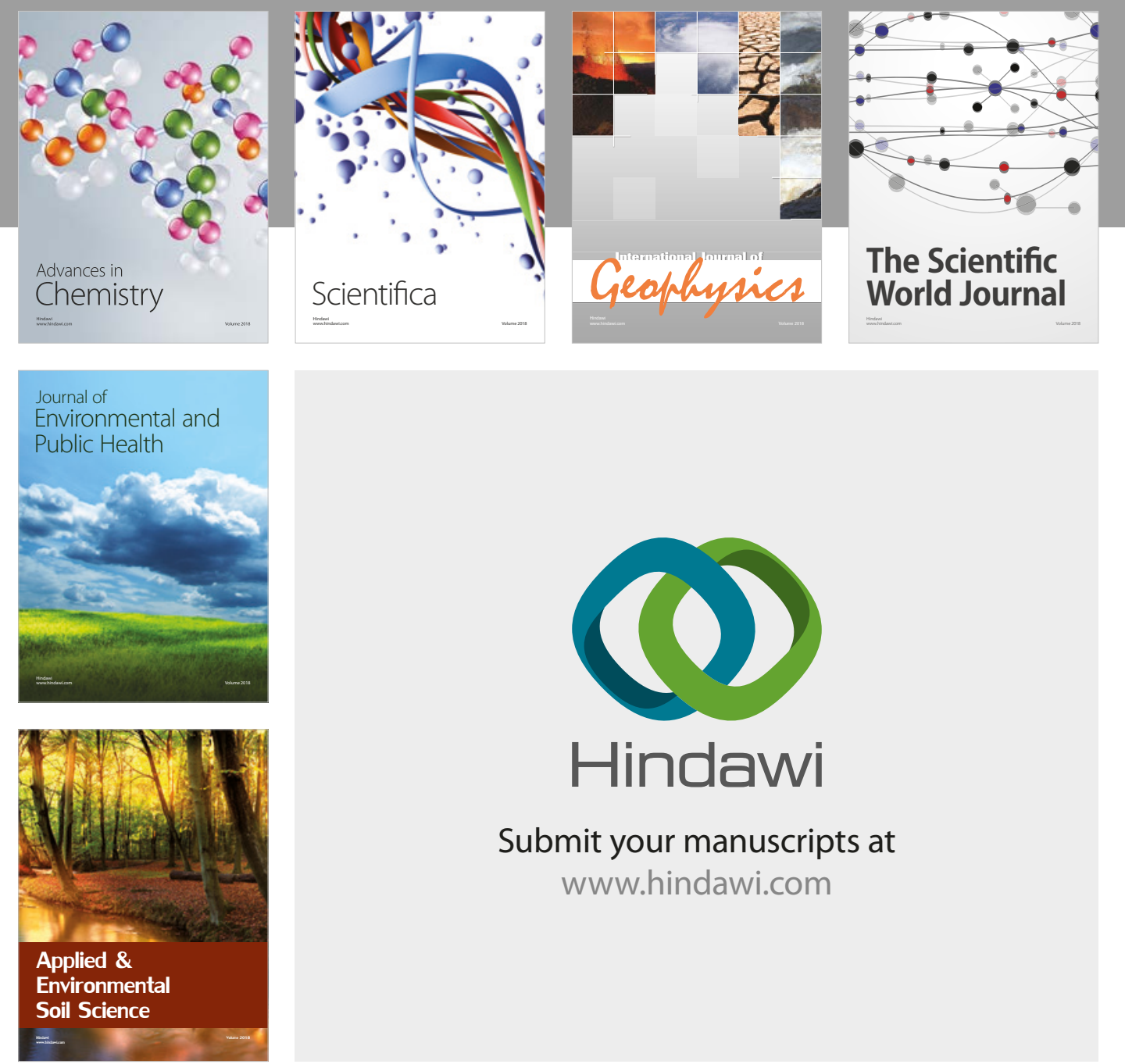

The Scientific

\section{World Journal}
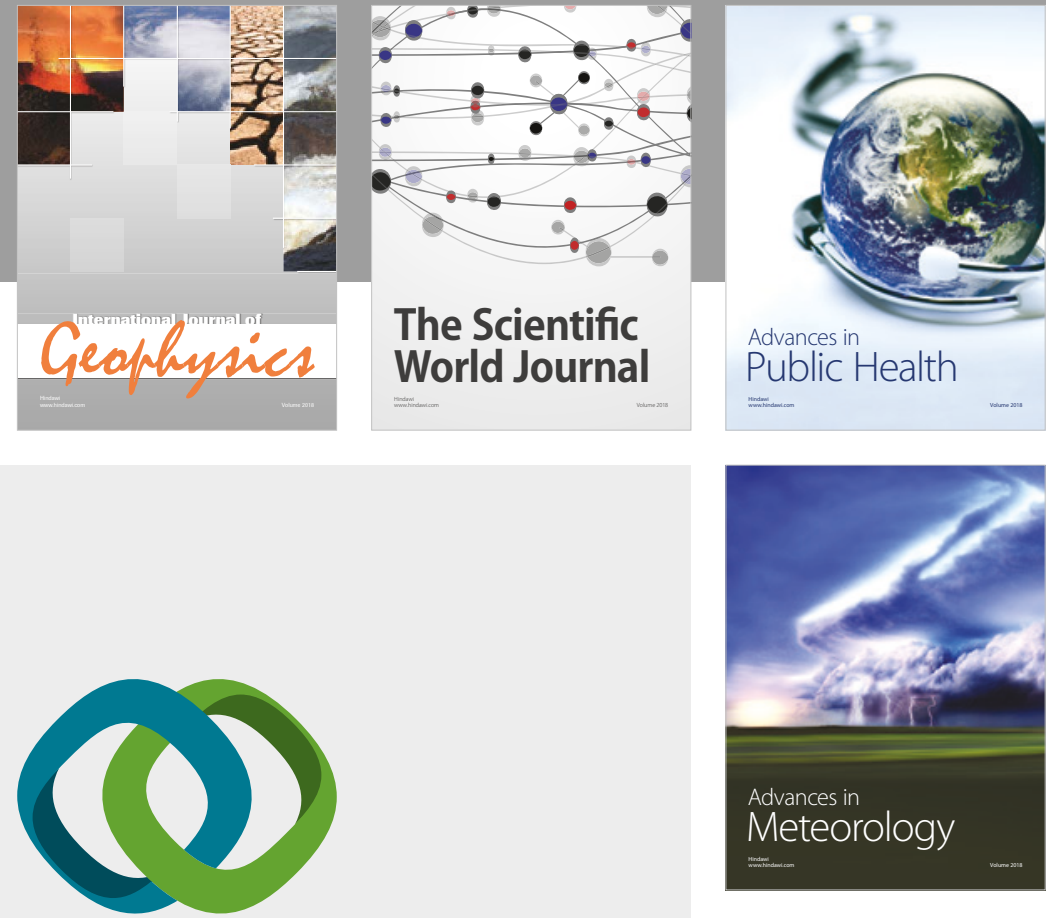

Advan

Public Health

\section{Hindawi}

Submit your manuscripts at

www.hindawi.com
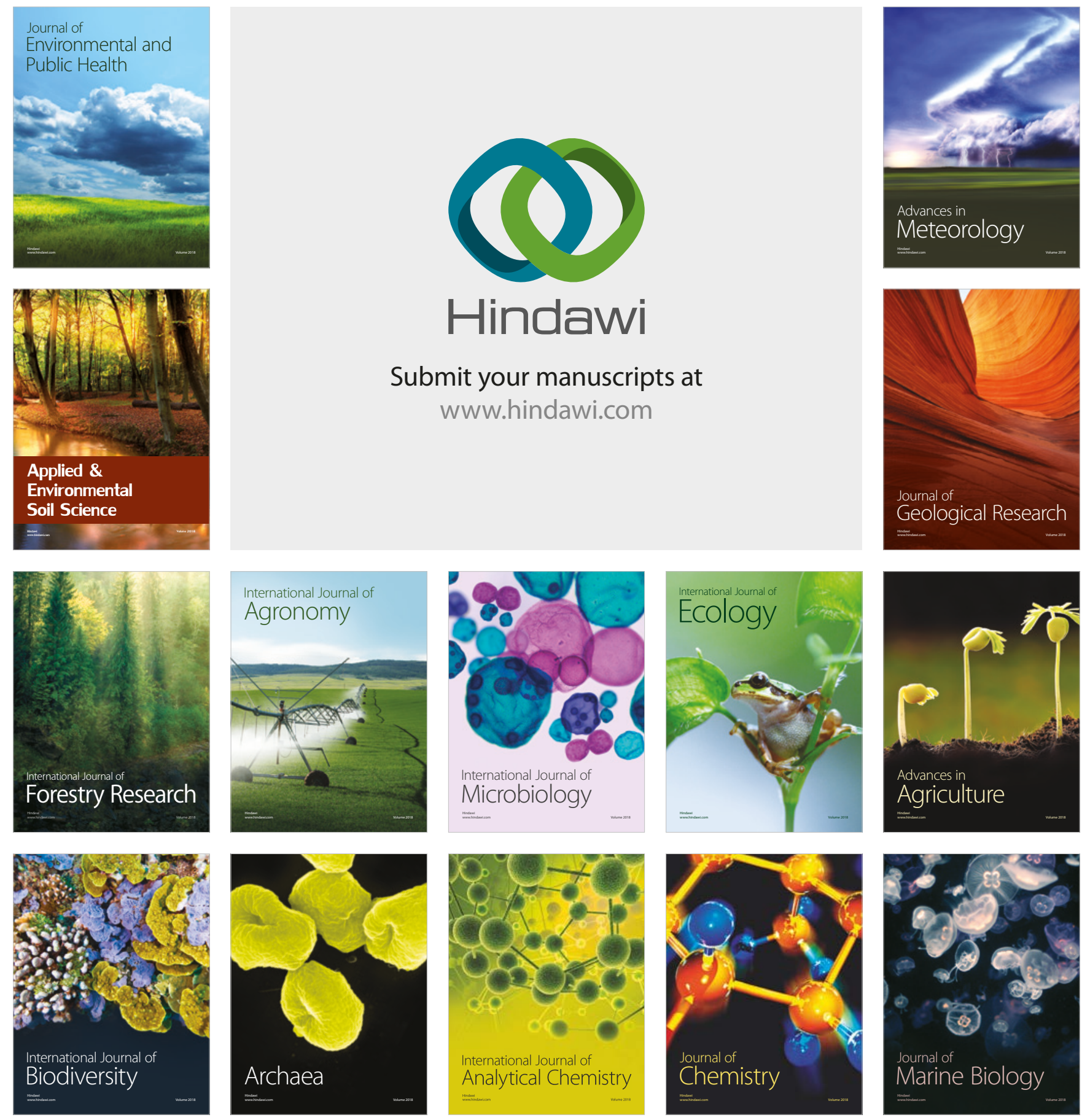